\title{
Analysis and prognosis of radiation exposure following the accident at the Siberian chemical combine Tomsk-7
}

Vakulovski, S.M.; Shershakov, V.M.; Borodin, R.V.; Vozzhennikov, O.I.; Gaziev, Y.I.; Kosykh, V.S.; Makhon'ko, K.P.; Chumichev, V.B.

\section{Publication date:}

1994

Document Version

Publisher's PDF, also known as Version of record

Link back to DTU Orbit

Citation (APA):

Vakulovski, S. M., Shershakov, V. M., Borodin, R. V., Vozzhennikov, O. I., Gaziev, Y. I., Kosykh, V. S., Makhon'ko, K. P., \& Chumichev, V. B. (1994). Analysis and prognosis of radiation exposure following the accident at the Siberian chemical combine Tomsk-7. Risø National Laboratory. Denmark. Forskningscenter Risoe. Risoe-R No. 750(EN)

\section{General rights}

Copyright and moral rights for the publications made accessible in the public portal are retained by the authors and/or other copyright owners and it is a condition of accessing publications that users recognise and abide by the legal requirements associated with these rights.

- Users may download and print one copy of any publication from the public portal for the purpose of private study or research.

- You may not further distribute the material or use it for any profit-making activity or commercial gain

- You may freely distribute the URL identifying the publication in the public portal 


\section{Analysis and Prognosis of Radiation Exposure Following the Accident at the Siberian Chemical Combine Tomsk-7}

S.M. Vakulovski, V.M. Shershakov, R.V. Borodin, O.I. Vozzhennikov, Ya.I. Gaziev, V.S. Kosykh, K.P. Makhon'ko, and V.B. Chumichev

Risø National Laboratory, Roskilde, Denmark October 1994 


\section{Analysis and Prognosis of Riso-R-750(EN) Radiation Exposure Following the Accident at the Siberian Chemical Combine Tomsk-7}

S.M. Vakulovski, V.M. Shershakov, R.V. Borodin, O.I. Vozzhennikov, Ya.I. Gaziev, V.S. Kosykh, K.P. Makhon'ko, and V.B. Chumichev

Scientific Production Association "Thyphoon"

Ris $\varnothing$ National Laboratory, Roskilde, Denmark October 1994 


\begin{abstract}
On the basis of the work (ground investigations and gamma zerial surveys) carried out jointly by the Rosgidromet organizations and Berezovgeologiya, data on the radiation exposure in Russia were obtained shortly after the accident of April 6, 1993 already. These data were transmitted to interested institutions.

The measurements performed on April 11 and 12, 1993 indicated that within the isolines of $10 \mu \mathrm{R} / \mathrm{h}$ a contaminated area of up to $25 \mathrm{~km}$ in length and up to $6 \mathrm{~km}$ in width extended towards the northeastern direction. Thus, the contaminated area outside of the premises of the combine covered about $100 \mathrm{~km}^{2}$. The total amount of radioactive substances in this area was $530-590 \mathrm{Ci}$. Isotope composition of the radioactive trace was determined by ruthenium-103 (1\%), ruthenium-106 (31\%), zirconium-95 (22\%), niobium-95 (45\%) and plutonium-239 (0.02\%).

Contamination heterogeneity is caused by the existence of "hot" particles with an activity of up to $10-11 \mathrm{Ci} /$ particle.

In the contaminated area the gamma exposure rate varied between 14 and 42 $\mu \mathrm{R} / \mathrm{h}$ at $\mathrm{I} \mathrm{m}$ height, yielding the maximum external radiation dose $100 \mathrm{mrem} / \mathrm{year}$ for the pupulation of Georgievka. The Pu-239 inlialation dose of the population of Georgievka when passing the radioactive cloud did not exceed 1.5 mrem.

A prognosis was made with regard to water contamination of the rivers Samuska and Tom during the flood in spring. Furthermore, contamination of the air layer adjacent to the ground resulting from the wind transport of radionuclides in the summer months at Georgievka was predicted. The values were far below the limits fixed according to the valid radiation protection regulations. However, that radionuclide concentration of the snow water may exceed the limits specified for drinking water.

According to the data measured by the meteorological stations, the radioactive products were not entrained beyond the borders of the country. Source estimation was successfully obtained using RIMPUFF, the Risø on-line puff diffusion model, in backfitting mode.
\end{abstract}

The basic translation of this report from Russian into English was done by the translation office at Kernforschungszentrum Karlsruhe, Germany.

ISBN 87-550-1980-3

ISSN 0106-2840

Grafisk Service - Risø 1994 


\section{Contents}

\section{Introduction 5}

1 Measures Taken by the Russian Federal Survey for Hydrometeorology and Environmental Monitoring After the Accident 5

2 Results of the Isotope Analysis of Snow and Soil Samples ?

3 Spread of the Radionctive Products in the Atmosphere and Contamination of the Ground Due to Their Deposition

4 Prognosis of Contamination Resulting from

Secondary Wind Transport 19

5 Prognosis of Water Contamination 21

5.1 Estimated Radionuclide Concentration of the Samuska River 21

5.2 Contamination of the flood in spring 21

5.3 Estimation of radionuclide washout 22

6 Supply of Information for the Estimation of Radiation Exposure in the Area of the Siberian Chemical Combine 29

6.1 Information for the taking of appropriate measures during the first hours after the accident 23

6.2 Systematization of the measured values and data processing for an objective radiation analysis 29

Annex 1$\} 2$

References 44 



\section{Introduction}

According to the report about the state of isdiation in the area affected by the accident at the Siberian chemical combine (Tomsk- 7 ), which was submitted by the Commission of the Russian State Committee for States of Emergency [1], the $\mathrm{N6102/2}$ facility of the radiochemical plant was destroyed on April 6, 1993 at 12.58. In this facility, a uranium solution had been prepared for extraction. During the explosion, part of the activity was released into the environment. It can be concluded from the activity data of the uranium solution published by the chemical combine that $500 \mathrm{Ci}$ beta-active and $20 \mathrm{Ci}$ alpha-active products including 19.3 Ci plutonium-239 had been contained in the facility prior to destruction.

Explosion resulted from the decomposition of the organic phase of the solution when interacting with concentrated nitric acid. The limited steam/gas volume released into the hall expladed. Thus, the extent of the damage was increased even furtber. Activity release into the atmosphere took place via the ventilation system, the pressure and vacuum lines, the $150 \mathrm{~m}$ high stack of building no. 205, the ventilation system and stack of building no. $20 \mathrm{l}$ as well as via the destrojed walk.

Immediately after Rosgidromet had been notified of the accident, measurements were started and radiation exposure in the area affected was analyzed in accordance with the regulations regarding "The Measures to be Taken by the Rosgidromet Divisions in Case of Nuclear Accidents".

\section{Measures Taken by the Russian Federal Sur- vey for Hydrometeorology and Environmental Monitoring After the Accident}

At 18.45 local time Rosgidromet was informed about the accident. To determine the contaminated area, all hydrometeorological stations and aeronautical meteorological offices of the monitoring network established by Rosgidromet were ordered to measure the gamma dose rate and the meteorological parameters every hour. The data obtained were then to be made available to Rosgidromet and other interested institutions. These values allowed a preliminary estimation of the extent of contamination to be accomplished. It turned out that contamination was entirely local.

As far as geography is concerned, the contaminated area is slightly hilly with only small differences in altitude $(30 \mathrm{~m})$. In the northern part, the territory is mainly covered by coniferous forest with dense underwood. In the south, mixed forest as well as bushes and slirubs are prevailing. Population density amounts to $80 \%$. Heights of 10 to $12 \mathrm{~m}$ are reached by the trees. About $20 \%$ of the territory is made up of swamps. Nearly $10 \%$ is under agricultural use. From east to west, the area is crossed by the Samuska river flowing in strong meanders. A maximum water flow rate of up to $70 \mathrm{~m}^{3} / \mathrm{s}$ is attained. The mean annual water flow rate is $10 \mathrm{~m}^{3} / \mathrm{s}$. While in the northeastern part, the territory is mainly loamy (70\%), soil , in the southwestern part is fc nd to be predominantly sandy.

The values measured by the synoptic aerological stations nearby, the meteorological data determined every 30 minutes in Tomsk (table 1.1) and the balloon data measured at Tomsk airport (table 1.2) led to the following conclusions: 
Take 1.1. Date meesered by the Tomst meteorological station on April 6. Isss

\begin{tabular}{|c|c|c|c|c|c|c|}
\hline Time & $\begin{array}{l}\text { Wind } \\
\text { Dir. } \\
\text { (deg.) }\end{array}$ & $\begin{array}{c}\text { Wind } \\
\text { Speed } \\
\mathrm{m} / \mathrm{s}\end{array}$ & $\begin{array}{c}\text { Air } \\
\text { Temp. } \\
{ }^{\circ} \mathrm{C} \\
\end{array}$ & $\begin{array}{c}\text { Ret. } \\
\text { Hum. } \\
x\end{array}$ & $\begin{array}{l}\text { Preci- } \\
\text { pitz- } \\
\text { tion }\end{array}$ & $\begin{array}{c}\text { Degree } \\
\text { of } \\
\text { Cloudiness }\end{array}$ \\
\hline $11: 00$ & 190 & $8-11$ & -4.3 & 79 & - & $10 / 3$ \\
\hline $11: 30$ & 200 & $i-10$ & -4.0 & 80 & - & cirrostratus \\
\hline $12: 00$ & 200 & $8-11$ & -3.8 & 80 & - & strato-cumulus clouds \\
\hline $12: 30$ & 210 & $8-11$ & -3.5 & 81 & - & 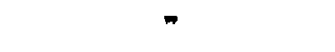 \\
\hline 13:00 & 190 & $9-12$ & -3.2 & $\pi$ & - & $m$ \\
\hline $13: 30$ & 210 & $9-12$ & -3.2 & $\pi 7$ & - & " \\
\hline 14:00 & 200 & $10-13$ & -2.9 & 67 & - & " \\
\hline $14: 30$ & 210 & $9-13$ & -2.6 & 65 & - & " \\
\hline 15:00 & 200 & $8-12$ & -2.3 & 68 & - & " \\
\hline $15: 30$ & 200 & $9-13$ & -2.0 & 71 & $15^{14}-17^{35}$ & " \\
\hline $16: 00$ & 200 & $10-13$ & -2.0 & 81 & - & $\begin{array}{c}10 / 4 \\
\text { cirrostratus } \\
\text { strato-cumulus clouds }\end{array}$ \\
\hline
\end{tabular}

Table 1.2. Dale measured by the balloons

\begin{tabular}{|c|c|c|c|c|c|c|c|c|c|c|c|c|c|c|}
\hline \multirow{3}{*}{ Time } & \multicolumn{14}{|c|}{ altitude above ground (m) } \\
\hline & \multicolumn{2}{|c|}{ Ground Level } & \multicolumn{2}{|c|}{100} & \multicolumn{2}{|c|}{200} & \multicolumn{2}{|c|}{300} & \multicolumn{2}{|c|}{400} & \multicolumn{2}{|c|}{500} & \multicolumn{2}{|c|}{600} \\
\hline & dir. & $\mathrm{m} / \mathrm{s}$ & dir. & $\mathrm{m} / \mathrm{s}$ & dir. & $\mathrm{m} / \mathrm{s}$ & dir. & $\mathrm{m} / \mathrm{s}$ & dir. & $\mathrm{m} / \mathrm{s}$ & dir. & $\mathrm{m} / \mathrm{s}$ & dir. & $\mathrm{m} / \mathrm{s}$ \\
\hline 11:00 & 200 & 8 & 210 & $\bar{t}$ & 210 & 10 & 220 & 10 & 220 & 14 & 220 & 15 & 220 & 14 \\
\hline 14:00 & 200 & 10 & 200 & 9 & 200 & 10 & 210 & 10 & 210 & 12 & 210 & 15 & 220 & 14 \\
\hline $17: 00$ & 200 & 3 & 200 & 9 & 200 & 10 & 210 & 10 & 210 & 10 & - & - & - & - \\
\hline
\end{tabular}

- Weather conditions at the site of the accident - stable southwestern wind (190 - 210 deg.), speed $8-13 \mathrm{~m} / \mathrm{s}$, temperature $-3^{\circ} \mathrm{C}$; precipitation in the form of wet snow was recorded after the accident at 15:30 local time;

- stratification - neutral.

For determining radiation exposure in the area surrounding the combine, two teams of experts of the Institute for Hydrometeorology and Environmental Monitoring. Division West Siberia (ZapSibgidromet), were established. The field measurements were performed at 16 villages and every 300 to $500 \mathrm{~m}$ on the roads from Tomsk to Samus and from Tomsk to Nelyubino. The highest contamination was found to exist on the road from Tomsk to Samus. Beginning at $\mathrm{km}$ 20, a strong increase in the gamma dose rate was observed. Maximum gamma dose rate was

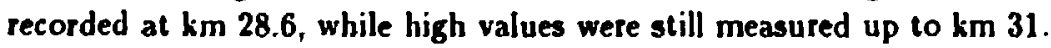

On the basis of the hydrometeorological data and the field measurements, the ZapSibgidromet and Rosgidromet experts were then able to determine the contaminated area within the $30-\mathrm{km}$ zone surrounding the chemical combine. As assumed by the experts, the trace of the radioactive cloud was directed towards the northeast having a length of up to $20 \mathrm{~km}[2,3]$.

Then, the trace dimensions as well as ground contamination inside the "spot" generated had to be determined more precisely. Appropriate methods had already been developed by the Rosgidromet divisions in close cooperation with the Russian Geological Committee when investigating the consequences of the accident at the 


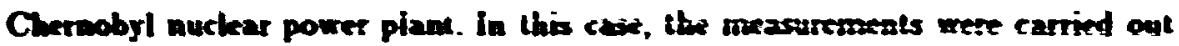
by ZapSibgidromet experts on 7 routes with a total length of $10 \mathrm{~km}$ under dificult conditions (deep snow in the taiga). Aximnthal determination of the gamma dose rete was accomplished every $100 \mathrm{~m}$. In addition, 25 snow samples were taken and analyed with regand to their concentrations of radionuclides and transauranium etemeats.

On behalf of the Rosgidromet Institute for Global Climate and Ecology and the Rusian Academy of Sciences, an acrial gamma survey was made of the 30-km zone surrounding the Tomsk- $T$ ehemical combine. Staf members of the statowned geological enterprise -Berezongeologiva" took part in this wort [3]. The plawe used for this purpose (AN-2) was equipped with a few-channel spectrometer having a Nal(TI)-8-erystal detector of $200 \times 100 \mathrm{~mm}$ in size and a lotal rohume of 251 . This device also served for measuring the gamma dose rate. Sensitivity amounted to 410 pulses per second for $1 \mu R / h$. Radionuclide composition was determined by recording samma radiation in the following eight intervals of the eacrey spectrum: 0.62 - $0.74 \mathrm{MeV}, 0.54-0.65 \mathrm{MeV}, 0.4-0.6 \mathrm{MeV}$, and 0.6 - 0.84 MeV for artificial radionuclides; the measurements for the natural radionuclides took place in the ranges close to the lines of 1.12, 1.76, 1.46 and $2.62 \mathrm{MeV}$.

Flight altitude was 70 to $100 \mathrm{~m}$. Following the aerial survey measurements, by means of which the general direction of transport and fallout of the radioactive products was found, detailed mapping of the snow-corered contaminated area in the scale of 1:100,000 was achieved on April 12 and 13, 1993 (distance between the measuring routes $I \mathrm{~km}$ ). The measuring routes were located at right angles to the axis of the radioactive trace and about $20 \mathrm{~km}$ long. The measurements started and ended outside of the trace. Thus, the outlines of the contaminated area could be identified. Calibration of the spectrometer installed in the plane was accomplished by repeated measurements. At the same time, snow samples were talen on the corresponding routes and the dose rate was measured using a dose meter of the type DRG-01. By comparison, a maximum root-mean-square error of the gamma dose rate measurements of $20 \%$ was determined.

The results of the gamma acrial survey and the comparative measurements at ground level were analyzed by the scientists involved in the activities and the experts of the Rosgidromet Institute for Global Climate and Ecology. They were found to be in good agreement.

\section{Results of the Isotope Analysis of Snow and Soil Samples}

From April 7 to April 12, 1993, isotope composition and concentration of the radioactive products deposited on the ground were determined by the ZapSibgidromet experts by means of 27 snow and 10 soil samples. In Fig. 2.1 the sampling is represented schematically. The samples were then analyzed in the laboratories of ZapSibgidromet and SPA "Typhoon", respectively.

Gammaspectrometric analysis was carried out in accordance with the regulations issued by the interauthority commission of the USSR State Committee for Hydrometeorology and Environmental Monitoring (Goskomgidromet). Spectrometers with germanium-litlium detectors and an energy resolution of $3-4 \mathrm{keV}$ for the 1336-keV line were applied. The results obtained by the Scientific Production Association "Typhoon" are presented in tables 2.1 and 2.2. The statistical error of the measured lata varies between 5 and $25 \%$.

Gammaspectrometric analysis revealed that ruthenium- 103 and -106 , zirconium95 and niobium-95 were contained in the samples. By measurement of two snow 
sanples over a perwod of to bours, trace amounts of cerium-itt and antinony-i25 (10 - $\left.50 \mathrm{mCi} / \mathrm{km}^{2}\right)$ were detected. Separate sammapectrometric analysis of the supeaded and discolved fractions of the mor samples resulted in the finding that more than $80 \%$ of the activity was bound to the suspended fraction. Gamma spectronetry of molten saon samples without prior separation into a suspeaded and a divolved fraction therefore yielded far too bigh results that could not be waed Gor quantitative extimation of contamiantion. Nerertheless, the isolope componition and the share of the individual ioolopes in tolal coatamination can still be specified.

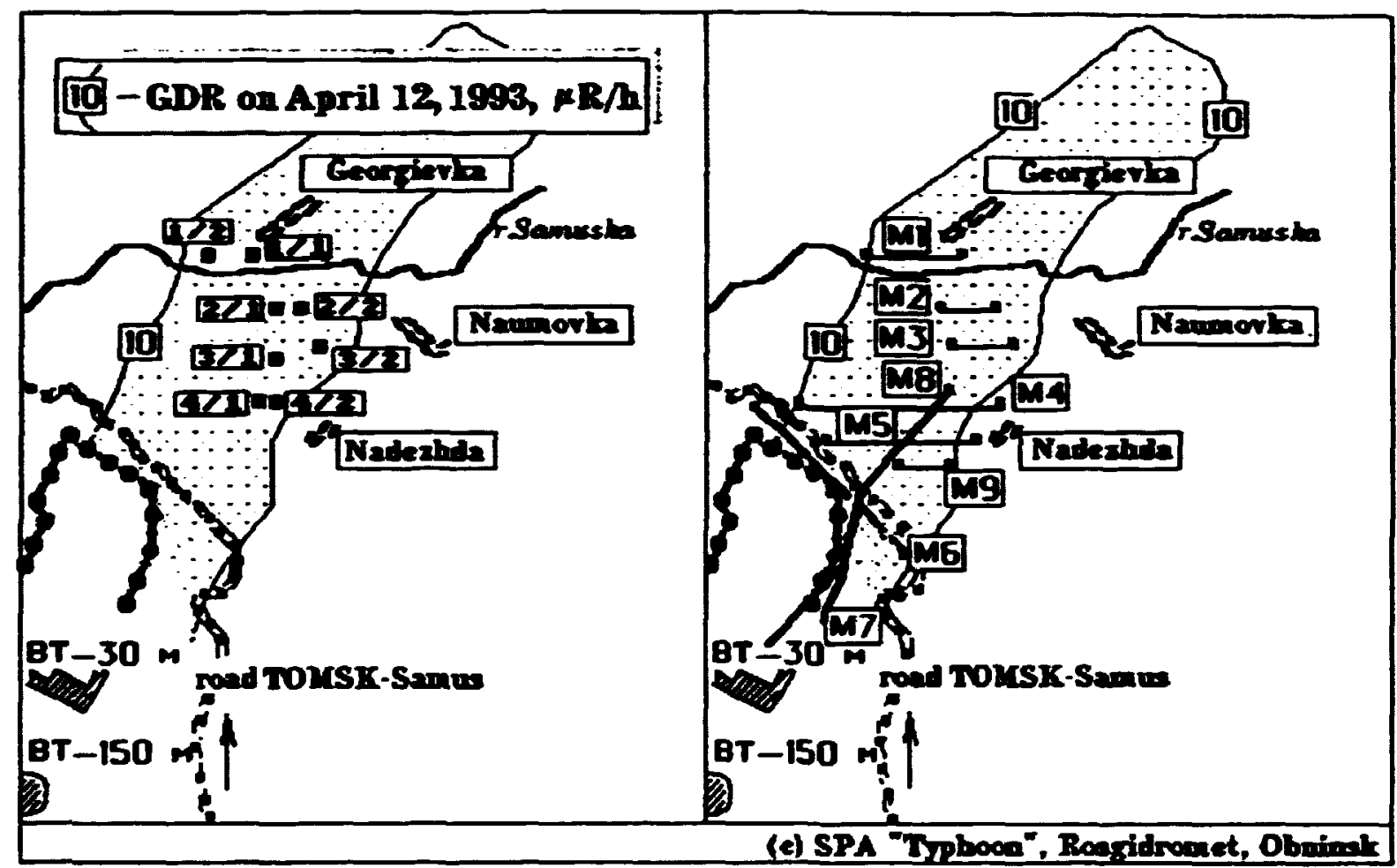

Figere 2.1. Figure 2.1a shows a schematic represention of the measuring routes, and figure 2.16 a schematic representation of the sampling on April 12, 1999.

Comparison of the values obtained by SPA "Typhoon" and ZapSibgidromet for the suspended and discolved fraction of the soil and snow samples did not reveal any systematic deviations. However, a scattering factor of 4-5 was reached. Scattering of the data can be explained by the inhomogeneous radioactivity of the samples, which is due to the existence of "hot" particles.

By means of gamma spectrometry of the soil samples, it was found out that the cesium-137 content exceeded gross contamination by a factor of 2-7. The latter had been caused by the emission of cesium-137 during the previous years of operation of the Siberian chemical combine. Existence of this contamination had been confirmed by the investigation results of the ZapSibgidromet experts in the years before the accident.

In numerous snow samples analyzed by SPA "Typhoon", also plutonium-239 and strontium-90 were identified. For plutonium-239 analysis, a method similar to that developed by the V.I. Vernadski Institute for Geochemistry and Analytical Chemistry was applied [4]. Plutonium-242 served as the tracer. The impurity components were removed by an anion exchange resin. Electrolytic separation of 
Tall 2.1. Snow and soil samples teten in the aree effected by the acrident (Tomst-7)

\begin{tabular}{|c|c|c|c|c|c|c|c|}
\hline \multirow{2}{*}{$\begin{array}{c}\text { Sample } \\
\text { No. }\end{array}$} & \multirow{2}{*}{$\begin{array}{l}\text { Radia } \\
\text { tion } \\
\boldsymbol{\mu R / \mathbf { h }}\end{array}$} & \multirow{2}{*}{$\begin{array}{c}\text { Susp-F }-F \\
\text { Sol-R } \\
\text { Soil }\end{array}$} & \multicolumn{5}{|c|}{ Actirity, $\mathrm{Ci} / \mathrm{km}^{2}$} \\
\hline & & & $R u-103$ & $\mathrm{Ru}-106$ & Zr-95 & Mb-95 & Cs-13i \\
\hline \multirow[t]{5}{*}{$\overline{3}$} & 70 & $\bar{F}$ & 0.0018 & 1.13 & 0.843 & 1.65 & \\
\hline & & $\mathbf{R}$ & 0.049 & 0.059 & 0.022 & 0.024 & \\
\hline & & $F+R$ & 0.072 & 1.2 & 0.865 & 1.67 & \\
\hline & & Soil & 0.020 & 0.43 & 0.173 & 0.34 & 0.222 \\
\hline & & Tolal & 0.058 & 1.63 & 1.04 & 2.02 & $0.2 m$ \\
\hline \multirow[t]{5}{*}{4} & 120 & $\bar{F}$ & 0.105 & 1.89 & 1.09 & 2.06 & \\
\hline & & $\boldsymbol{R}$ & 0.000 & 0.179 & 0.05 & 0.058 & \\
\hline & & $F+R$ & 1.115 & 2.07 & 1.14 & 2.14 & \\
\hline & & Soil & 0.223 & 8.32 & 6.00 & 15.6 & 0.14 \\
\hline & & Total & 0.358 & 10.4 & 7.2 & $17 . \bar{T}$ & 0.14 \\
\hline \multirow[t]{5}{*}{ T } & 100 & F & 0.008 & 1.46 & 0.834 & 1.73 & \\
\hline & & $\mathbf{R}$ & 0.0003 & 0.0053 & 0.009 & 0.016 & \\
\hline & & $\mathbf{F}+\mathbf{R}$ & 0.065 & 1.52 & 0.893 & 1.75 & \\
\hline & & Soil & 0.061 & 1.36 & 0.949 & 1.98 & 0.435 \\
\hline & & Total & 0.125 & 2.88 & 1.84 & 3.73 & 0.435 \\
\hline \multirow[t]{5}{*}{8} & 131 & $\bar{F}$ & 0.253 & 4.73 & 3.51 & 6.78 & \\
\hline & & $\mathbf{R}$ & 0.015 & 0.335 & 0.09 & 0.137 & \\
\hline & & $\mathbf{F}+\mathbf{R}$ & 0.268 & 5.05 & 3.60 & 6.91 & \\
\hline & & Soil & 0.086 & 1.99 & 1.50 & 3.44 & 0.271 \\
\hline & & Tolal & 0.354 & 7.05 & 5.10 & 10.3 & 0.271 \\
\hline \multirow[t]{3}{*}{9} & 123 & $\bar{F}$ & 0.21 & 4.40 & 3.24 & 10.0 & \\
\hline & & $\mathbf{R}$ & 0.006 & 0.228 & 0.085 & 0.311 & \\
\hline & & $F+R$ & 0.216 & 4.63 & 3.32 & 10.3 & \\
\hline 5 & $\pi$ & Soil & 0.21 & 4.99 & 3.34 & 9.8 & 0.44 \\
\hline
\end{tabular}

the sample to be counted took place on a stainless steet target. Alpha radiation of plutonium-239 was measured using a spectrometer of the type 570 A-450 R manulactured by the "ORTEC" company. Strontium-90 was determined in accordance with the methods outlined in [5]. They had already been applied in 1990 , when SPA "Typhoon" investigated intercalibrated IAEA samples with regard to their plutonium-239, plutonium-240 and strontium-90 contents. Agreernent of the results with the basic values was found to be rather good.

The analytical results obtained with regard to the Pu-239 concentration of both suspensions of the particles contained in the snow water of the snow samples studied and filtered water samples are presented in table 2.3. According to the values indicated for the first five samples, at least $90 \%$ of the Pu-239 activity of the snow is bound to the water-insoluble, disperse phase of the radioactive fallout. $A$ mean of $4 \%$ of the activity is found in the soluble phase only. For subsequent analysis, suspensions filtered from the snow water samples were applied. It is evident from the data given in table 2.3 that the densities of $\mathrm{Pu}-239$ deposition on the snow exceeded $0.06 \mathrm{mCi} \times \mathrm{km}^{-3}$. However, they were far below the maximum permiscible ground contamination $\left(100 \mathrm{mCi} \times \mathrm{km}^{-2}\right)$ specified in April 1086 after the Chernobyl accident. 
Telt 2.2. Snor semples taten in the eres affected by the accilent (Tomst-T)

\begin{tabular}{|c|c|c|c|c|c|c|c|c|}
\hline \multirow{2}{*}{ Romile } & \multirow[b]{2}{*}{$\begin{array}{c}\text { Sample } \\
\text { No. }\end{array}$} & \multirow[b]{2}{*}{$\begin{array}{l}\text { Date of } \\
\text { samplians }\end{array}$} & \multirow{2}{*}{$\begin{array}{l}\text { Radia } \\
\text { lion } \\
\text { RR/h }\end{array}$} & \multirow{2}{*}{$\begin{array}{c}\text { Suspo- }-F \\
\text { Sol-R } \\
\text { Toral } F+R\end{array}$} & \multicolumn{4}{|c|}{ Activity, $\mathrm{Ci} / \mathrm{hm}^{2}$} \\
\hline & & & & & Ru-I03 & Ru-106 & $2 r-95$ & $\mathrm{Nb}-95$ \\
\hline $\mathbf{M - 1}$ & 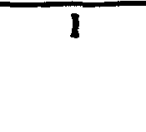 & 12.04 .93 & 30 & $\begin{array}{c}\mathbf{F} \\
\mathbf{R} \\
\mathbf{F}+\mathbf{R}\end{array}$ & $\begin{array}{l}0.021 \\
0.021\end{array}$ & $\begin{array}{l}0.286 \\
0.206\end{array}$ & $\begin{array}{l}0.18 \\
0.02 \\
0.20\end{array}$ & $\begin{array}{l}0.465 \\
0.035 \\
0.50\end{array}$ \\
\hline$M-1$ & 2 & 12.04 .93 & $\overline{23}$ & $\begin{array}{c}\mathbf{F} \\
\mathbf{R} \\
\mathbf{F}+\mathbf{R}\end{array}$ & $\begin{array}{l}0.061 \\
0.061\end{array}$ & $\begin{array}{l}1.304 \\
1.304\end{array}$ & $\begin{array}{l}0.993 \\
0.018 \\
1.011\end{array}$ & $\begin{array}{l}1.97 \\
0.028 \\
2.0\end{array}$ \\
\hline $\mathbf{M - 2}$ & 1 & 12.04 .93 & 72 & $\begin{array}{c}F \\
R \\
F+R\end{array}$ & $\begin{array}{l}0.092 \\
0.092\end{array}$ & $\begin{array}{l}2.98 \\
0.05 \\
2.13\end{array}$ & $\begin{array}{l}1.51 \\
0.042 \\
1.55\end{array}$ & $\begin{array}{l}2.84 \\
0.071 \\
2.91\end{array}$ \\
\hline $\mathbf{M - 3}$ & 1 & 12.04 .93 & 206 & $\begin{array}{c}\mathbf{F} \\
\mathbf{R} \\
\mathbf{F}+\mathbf{R}\end{array}$ & $\begin{array}{l}0.137 \\
0.034 \\
0.171\end{array}$ & $\begin{array}{l}3.01 \\
0.843 \\
0.305\end{array}$ & $\begin{array}{l}.11 \\
0.559 \\
2.67\end{array}$ & $\begin{array}{l}3.67 \\
1.036 \\
4.71\end{array}$ \\
\hline$M-1$ & 2 & 112.04 .93 & 96 & $\begin{array}{c}\mathbf{F} \\
\mathbf{R} \\
\mathbf{F}+\mathbf{R}\end{array}$ & $\begin{array}{l}0.07 \\
0.007 \\
0.077\end{array}$ & $\begin{array}{l}1.62 \\
0.154 \\
1.07\end{array}$ & $\begin{array}{l}1.01 \\
0.096 \\
1.11\end{array}$ & $\begin{array}{l}1.90 \\
0.195 \\
2.095\end{array}$ \\
\hline $\begin{array}{l}\text { Georgi } \\
\text { village } \\
\text { field pa }\end{array}$ & $\begin{array}{l}\text { rta, } \\
\text { boundary } \\
\text { th }\end{array}$ & 0.7 .04 .93 & & $\begin{array}{c}\mathbf{F} \\
\mathbf{R} \\
\mathbf{F}+\mathbf{R}\end{array}$ & $\begin{array}{l}0.019 \\
0.019\end{array}$ & $\begin{array}{l}0.403 \\
0.032 \\
0.435\end{array}$ & $\begin{array}{l}0.224 \\
0.013 \\
0.237\end{array}$ & $\begin{array}{l}0.358 \\
0.027 \\
0.385\end{array}$ \\
\hline $\begin{array}{l}\text { George } \\
\text { village } \\
\text { house } \\
\text { froat : }\end{array}$ & $\begin{array}{l}\text { rla } \\
\text { boundary } \\
\text { o. } 6 \\
\text { rd }\end{array}$ & 08.04 .93 & & $\begin{array}{c}\mathbf{F} \\
\mathbf{R} \\
\mathbf{F}+\mathbf{R}\end{array}$ & $\begin{array}{l}0.023 \\
0.023\end{array}$ & $\begin{array}{l}0.566 \\
0.10 \\
0.666\end{array}$ & $\begin{array}{l}0.432 \\
0.046 \\
0.478\end{array}$ & $\begin{array}{l}0.919 \\
0.107 \\
1.03\end{array}$ \\
\hline
\end{tabular}

Tolk 2.9. Deasily of serface contaminetion of the snow by plulonium-29y

\begin{tabular}{|c|c|c|c|}
\hline $\begin{array}{l}\text { No. or desig- } \\
\text { nation of } \\
\text { the sample }\end{array}$ & $\begin{array}{l}\text { Anal. fraction } \\
\text { Suspension (F) } \\
\text { Filtrate (R) }\end{array}$ & $\begin{array}{c}\text { Surface contamina } \\
\text { tion of the snow } \\
\mathrm{mCl} \times \mathrm{km}^{-2}\end{array}$ & $\begin{array}{c}\text { Pu-239/Zr-95 } \\
\text { activity ratio } \\
\text { \% }\end{array}$ \\
\hline \multirow[t]{2}{*}{$\overline{\overline{3}}$} & $\bar{F}$ & 0.3 & $\overline{\overline{0.036}}$ \\
\hline & $\mathbf{R}$ & $0.00 i$ & \\
\hline \multirow[t]{2}{*}{4} & F & 0.15 & 0.014 \\
\hline & $\mathbf{R}$ & 0.017 & \\
\hline \multirow[t]{2}{*}{7} & $\bar{F}$ & 0.4 & 0.045 \\
\hline & $\mathbf{R}$ & 0.0032 & \\
\hline \multirow[t]{2}{*}{8} & $\bar{F}$ & 1.2 & 0.037 \\
\hline & $\mathbf{R}$ & 0.043 & \\
\hline \multirow[t]{2}{*}{9} & $\bar{F}$ & 1.2 & 0.037 \\
\hline & $\mathbf{R}$ & 0.023 & \\
\hline$M-1-1$ & $\bar{F}$ & 0.06 & 0.032 \\
\hline$M-1-2$ & $\boldsymbol{F}$ & 0.3 & 0.03 \\
\hline$M-2-1$ & $F$ & 0.63 & 0.042 \\
\hline$M-2-2$ & $\mathbf{F}$ & 0.35 & 0.035 \\
\hline$M-4-2$ & $\mathbf{F}$ & 0.35 & 0.035 \\
\hline Georgievka, 6 & F & 0.12 & 0.028 \\
\hline
\end{tabular}


The ralues given in table 2.3 (last columa) are required for the dithrmination of the conuresion factors. Ising the factors. the Pu-210 content of the radionctive fallowt may be calculated from the xirconium-9s activity that can be measured easily. The mean value of the Pu-239/2 -95 axtivity ratios indicated in table 2.3 is $3.4 \times 10^{-t}$. The root-mean-square error of the measurements and the mean value amounts to $8 \times 10^{-3}$ and $2.6 \times 10^{-5}$, respectively. From this it may be concluded that the mean value of the ratios above amounts to $(3.4 \pm 0.6) 10^{-4}$ with a probability of 0.95 . The conuersion factor from the zirconium-95 actirity meanered is a sample to its Pu-239 content ranges from $1.6 \times 10^{-4}$ to $5.2 \times 10^{-4}$. Thes, the mod probable surface dewaity at the sampling point of the saow sample 4-3-1, the plutonium-239 coatent of which was mot analyaed radiochemically, was Lond to be about I $\mathrm{mCi} \times \mathrm{km}^{-2}$. With a probability of 0.95 , the value of 1.4 $\mathrm{mCl} \times \mathrm{km}^{-2}$ was nol exceeded.

The snow sample M-3-1 (or to be more precise, the portion analyud by SPA Typhoos") was applied for preliminary extimation of the surface densily of uranimm depesition in the controlled area. According to the data published by the Siberian chemical combine, 8713 to uraium had been coatained in the 6102/2 facility prior to the arcident [1]. This o doe almost completely referred to uranium238. The fractions of the of her uranium isotopes were extremely small. The uranium230 conteat of the sample to be investigated was determined by means of neutron activation analysis. It was found that surface density of the uranium-23s deposition on the snow amounted to $100 \mathrm{~g} \times \mathrm{km}^{-3}$ at the sampling point of sample M-3-1. Surface density of the alpha-activity resulting from uranium-238 was 0.16 $\mathrm{mCl} \times \mathrm{km}^{-2}$. This value nuxy be derived from the known specific alpha-activity of uranium-235 of $3.34 \times 10^{--} \mathrm{Ci}^{-1} \mathrm{~s}^{-1}$. As the surface density of Pu-239 depasition on the smow amounted to about $1 \mathrm{mCi} \times \mathrm{km}^{-2}$ at this point, the uranium-238/Pu250 axtivity ratio of the atmospheric radioactive falbul was 0 . I6. This value corresponded to that of these radionuclides $(0.15)$ in the source of radiaactive emission into the atmosphere. The most important data obtained by the laboratory of the National Health Setvice with regard to the surface densities of the radioactive Pu-239 and uranium-235 depositions on the snor are reported about in [1] and summarized in lable 2.4 .

According to the data given in tables 2.3 and 2.1. the surface densities of plutonium-239 deposition on the snok at Grorgievila are $0.12 \mathrm{mCi} \times \mathrm{km}^{-2}$ and $0.20 \mathrm{mCi} \times \mathrm{km}^{-2}$. respectively. Hence, a mean value of $0.16 \mathrm{mCi} \times \mathrm{km}^{-2}$ is $\mathrm{nb}$ taimed. The deviations of the individual vaius measured from the mean value obviously result from macroscopic and microscopic inhomogeneities of the plutonium239 deposition field in the Crorgievia area. These inhomogeneities may be caused by most of the alpha- and beta-active products being deposited on the surface of the snow in the form of "hot" particles having beta-activities of $10^{-11} \mathrm{Ci} /$ particle and more. According to preliminary estimates, the deposition density of these partieks on the surface of the snow at the fringe of the Ceorgievka village (field path) amounted to about $4 \times 10^{2}$ particles $/ \mathrm{m}^{2}$. Now, the special features of ground contamination by "hot" radionctive particles and their physical and nuclear-physical charactetistics shall be investigated. According to table 2, values of (6.5 - 7.5$)$ $\mathrm{mCi} \times \mathrm{km}^{-2}$ were altained for the surface density of Pu-239 contamination at certain points in the snow. These values corresponded to those of the sections with the highest contamination. But even in these cases, the values were found to be far below the maximum permissible ground contamination by plutonium-239. At measuring points with the gamuza dowe rate ranging from 160 to $1800 \mu R \times$ $h^{-1}$, a mean value of the Pu-239/zirconium-95 activity ratio of $(1.0 \pm 0.34) \times 10^{-3}$ was obtained with a probabiitity of 0.05 . The individual values were found to be in the range of $(1.0 \pm 0.8) \times 10^{-3}$. Hence, they differed from the above eatimates for less contaminaled areas in the radioactive trace. It must he pointed out that so 
Table 2.4. Snow contamination by alpha-active producls in the radioactive trace [7].

\begin{tabular}{|c|c|c|c|c|c|c|}
\hline \multirow[t]{2}{*}{$\begin{array}{l}\text { Sampling } \\
\text { point }\end{array}$} & \multirow[t]{2}{*}{$\begin{array}{l}\text { Date } \\
1993\end{array}$} & \multirow{2}{*}{$\begin{array}{c}\text { Gamma } \\
\text { exposure } \\
\text { rate } \mu \mathrm{K} \times \mathbf{h}^{-1} \\
\end{array}$} & \multicolumn{3}{|c|}{$\begin{array}{l}\text { Snow contamination } \\
\text { by alpha-active radio- } \\
\text { nuclides } \mathrm{mCix} \mathrm{km}^{-2}\end{array}$} & \multirow{2}{*}{$\begin{array}{c}\text { Total alpha- } \\
\text { activity, } \\
\mathrm{mCi} \times \mathrm{km}^{-2} \\
\end{array}$} \\
\hline & & & $\mathrm{Pu}-239$ & $\mathrm{U}-238$ & $\mathrm{U}-234$ & \\
\hline $\mathrm{Km} 28$ & 06.04 . & 280 & 0.60 & 0.151 & 0.172 & 0.93 \\
\hline $\begin{array}{l}\text { Km } 28 \text { left- } \\
\text { hand side }\end{array}$ & 0.7 .04 & 400 & 7.51 & 0.707 & 0.619 & 8.94 \\
\hline $\begin{array}{c}\text { Km } 28 \text { right- } \\
\text { hand side }\end{array}$ & 07.04 & 400 & 5.28 & 0.815 & 0.424 & 6.52 \\
\hline Georgievka & 08.04 & 23 & 0.20 & 0.101 & 0.101 & 0.40 \\
\hline $\begin{array}{l}\mathrm{Km} 28 \\
(50 \mathrm{~m})\end{array}$ & 09.04 & 370 & 4.53 & 0.437 & 0.306 & 5.27 \\
\hline $\begin{array}{c}\text { Km 28 } \\
(300 \mathrm{~m})\end{array}$ & 9.04 & 350 & 2.43 & 0.334 & 0.576 & 3.34 \\
\hline $\begin{array}{c}\mathrm{Km} 28 \\
(600 \mathrm{~m})\end{array}$ & 09.04 & 157 & 0.59 & 0.020 & 0.020 & 0.65 \\
\hline $\begin{array}{c}18 \mathrm{Pl} \text {. } \\
\text { (righ-hand } \\
\text { side of path) }\end{array}$ & 10.04 & 1800 & 6.45 & 5.15 & 5.68 & $18.33^{1}$ \\
\hline
\end{tabular}

'The share of the uranium-235 portion of the sample measured in the total alphaactivity $\left(1.05 \mathrm{mCi} \times \mathrm{km}^{-2}\right.$ is also taken into account.

far only few measured values have been made available with regard to ground cont.rmination by $\mathrm{Pu}-239$ in the area affected by the accident at the Siberian chemical combine. To obtain more reliable data about the existing contamination, far more measurements have to be carried out.

Thirteen snow samples and 5 soil samples were analyzed by SPA "Typhoon" with a view to determine their strontium- 90 content. The results are presented in table 2.5. In the snow, this radionuclide was mainly found in the dissolved fraction, i.e., the snow water. $13 \%$ of the strontium- 90 was bound to the suspended particles only. According to our data, contamination density of the snow by strontium- 90 was the highest in samples nos. 8 and 9 . Here, values of 9.2 and $7.6 \mathrm{mCi} / \mathrm{km}^{2}$, respectively, were reached. Analysis of seven snow samples by ZapSibgidromet revealed that the strontium 90 concentration of sample $\mathrm{No} .1\left(18.5 \mathrm{mCi} / \mathrm{km}^{2}\right)$ was twice as high as the maximum value determined by SPA "Typhoon". The other strontium-90 values were in good agreement with the values determined by "Typhoon". Our values do not suggest any relation between the strontium- 90 content and the content of gamma emitters in the samples. This can be explained by the fact that the latter are predominantly encountered in the suspended particles of the snow, while strontium- 90 is mainly found in the snow water. At the measuring points, density of ground contamination by strontium- 90 varied between 140 and $250 \mathrm{mCi} / \mathrm{km}^{2}$. These values were much higher than the contamination of the surface of the snow. Gross background radiation $\left(35 \mathrm{mCi} / \mathrm{km}^{2}\right)$ was exceeded by a factor of 4-7. The higher ground contamination may result from emissions during previous operation of the combine. In certain areas, suclı emissions had been recorded by ZapSibgidromet experts in 1990 already. 
Table 2.5. Density of snow and ground contamination by strontium-90, mCi/km²

\begin{tabular}{|c|ccc|c|}
\hline $\begin{array}{c}\text { Sample } \\
\text { No. }\end{array}$ & \multicolumn{3}{|c|}{ Snow } & Soil \\
\cline { 2 - 5 } & Snow water & Suspension & Total & \\
\hline \hline 3 & 2.3 & & & 150 \\
4 & 3.4 & 0.26 & 3.6 & 140 \\
7 & 2.8 & 0.35 & 3.15 & 210 \\
8 & 8.5 & 0.7 & 9.2 & 250 \\
9 & 6.6 & 1.0 & 7.6 & 160 \\
$M-1-1$ & 0.3 & 0.04 & 0.34 & \\
$M-1-2$ & 0.5 & 0.03 & 0.53 & \\
$M-2-1$ & 0.5 & 0.07 & 0.57 & \\
$M-2-2$ & $<0.1$ & $<0.01$ & 0.11 & \\
$M-3-1$ & 0.5 & & & \\
M-4-2 & 0.4 & $<0.01$ & 0.41 & \\
Georgievka & & & & \\
field path & 0.55 & & & \\
Georgievka & & & & \\
house No. 6 & 0.6 & & & \\
\hline
\end{tabular}

\section{Spread of the Radioactive Products in the At- mosphere and Contamination of the Ground Due to Their Deposition}

On the basis of the total beta-activity values measured for the products contained in the facility, total activity was calculated to be $500 \mathrm{Ci}$ [1]. The activities of ${ }^{103} \mathrm{Ru},{ }^{106} \mathrm{Ru},{ }^{95} \mathrm{Zr}$ and ${ }^{95} \mathrm{Nb}$ are not indicated. With the calibration substance used when measuring the beta-activity of the samples assumed to be ${ }^{90} \mathrm{Sr}+{ }^{90} \mathrm{Y}$ (this substance was usually applied at the combine), the activity of the isotopes above can be derived from ratio between their activity and the total beta-activity of the snow samples. The latter was measured using a gamma spectrometer and the RUB-01P beta-system calibrated to ${ }^{90} \mathrm{Sr}+{ }^{90} \mathrm{Y}$.

On April 12, 1993, snow samples were taken by ZapSibgidromet experts along the measuring routes $\mathrm{M} 1$ through $\mathrm{M} 4$ as well as at the village of Georgievka. As already mentioned above, determination of the total beta-activity and gamma spectrometry of the samples were performed both at the regional ZapSibgidromet laboratory, Novosibirsk and at SPA "Typhoon" in Obninsk. The ratios between the activities of the individual isotopes and the total beta-activity of the snow samples $R / \beta$ as well as the calculated activities $Q_{0}$ of the individual isotopes in the facility exploded during the accident are given below:

$\begin{array}{cccccc}\text { Isotope } & { }^{103} \mathrm{Ru} & { }^{105} \mathrm{Ru} & { }^{95} \mathrm{Zr} & { }^{95} \mathrm{Nb} & \Sigma \\ \mathrm{R} / \beta & 0.069 & 2.3 & 1.3 & 3.0 & \\ \mathrm{Q}_{0} \mathrm{Ci} & 35 & 1150 & 650 & 1500 & 3300\end{array}$


Hence, 3000 - $3500 \mathrm{Ci}$ were contained in the facility prior to the explosion. Assuming that at least one third of the products contained in the facility was released, a release rate of $Q \sim 10^{3} \mathrm{Ci}$ is obtained. As mentioned in the introduction, the roof of building 201 had been partly destroyed by the explosion. On the weather side, explosion had torn a hole of $250 \mathrm{~m}^{2}$ in size into the wall. The explosion products were released via this hole, the brolien windows, the destroyed roof and the stack of building 201 as well as via the stack of the ventilation system of 150 $m$ in height (building 205) [1]. The individual activities released by each of these sources are not known.

In the Tomsk area and in the $100-\mathrm{km}$ zone surrounding the chemical combine, radioactive contamination is controlled regularly by the measuring and meteorological stations belonging to the ZapSibgidromet radiometrical network. Twenty-three dose control stations, 13 stations controlling radioactive fallout and one station for the control of the concentration of radioactive products in the air (Kolpashevo) are located in the Tomsk region. Following the accident at the chemical combine (Tomsk-7) with the release of radioactive products into the atmosphere, all stations of the ZapSibgidromet radiometrical network in the Tomsk region and in the adjacent areas of Novosibirsk and Kemerovo as well as the measuring stations of the Krasnoyarsk region were ordered in accordance with the valid regulations to carry out measurements of the gamma background until April 11, 1993. From April 6 to April 8, 1993, these measurements were carried out every hour. As of April 9, 1993, they took place every three hours. The gamma exposure rate measured by the measuring stations in the Tomsk region including the control stations in the $100-\mathrm{km}$ zone surrounding the chemical combine was found to vary between 6 aidd $15 \mu \mathrm{R} / \mathrm{h}$ on these days. The gamma exposure rates measured in the Tomsk area before and after the accident are presented in table 3.1. It is evident from the data below that gamma background in the $100-\mathrm{km}$ zone did not change after the accident of April 6, 1993. The measuring stations located in the Novosibirsk and Kemerovo areas also did not record any changes of gamma background after April 6, 1993. The mean gamma exposure rates determined by the measuring stations of the radiometrical network from April 6 to April 11, 1993 varied between 7 and $13 \mu \mathrm{R} / \mathrm{h}$ and 9 and $17 \mu \mathrm{R} / \mathrm{h}$ in the Novosibirsk and the Kemerovo area, respectively.

The mean values determined by the measuring stations of the Krasnoyarskgidromet from April 6 to April 11, 1993 are presented in table 3.2. For comparison, the mean gamma exposure rates of March 1993 are indicated as well. It can be noticed that the gamma background values measured by the radiometrical measuring stations in the regions adjacent to the Tomsk area did not change after the accident.

The trajectories of air transport calculated for a period of 67 hours following the explosion are represented in Fig. 6.1 for three different altitudes. They indicate that transport took place towards the northern and northeastern direction on the first three days after the accident. However, an increase in the gamma background had not been recorded by any of the Rosgidromet radiometrical network stations located in the direction of these trajectories.

The most sensitive method for controlling the radioactive products released into the air during an accident is the sampling of the atmospheric fallout and aerosols. Radioactivity is measured daily by the stations belonging to the radiometrical network. According to the data transmitted to "Typhoon" by the stations determining the total beta-activity of the sar.ples, a slight increase in the radioactivity concentration of the air and the precipitations was recorded by the Turukhansk station from A pril 8 to 10 only. On these days, atmospheric precipitation amounted to three times the mean value of the montl of March. Concentration of radioactive aerosols was increased by a factor of $1.5-2$. This, however, was still within the 
Table 9.J. Gamma exposure rates measured in the Tomst region before and during the first days after the accident at the chemical combine, $\mu R / h$.

\begin{tabular}{|c|c|c|c|c|c|c|c|c|c|c|}
\hline \multirow{2}{*}{$\begin{array}{l}\text { Control } \\
\text { station }\end{array}$} & \multirow{2}{*}{$\begin{array}{l}\text { Distance of } \\
\text { radiation } \\
\text { source, } k m\end{array}$} & \multirow{2}{*}{$\begin{array}{l}\text { Azi- } \\
\text { muth } \\
\text { deg. }\end{array}$} & \multirow{2}{*}{$\begin{array}{l}\text { Mean } \\
\text { value } \\
1992 \\
\end{array}$} & \multicolumn{7}{|c|}{ April 1993} \\
\hline & & & & $1-5$ & 6 & 7 & 8 & 9 & 10 & 11 \\
\hline Molchanovo & 140 & 325 & 12 & $12-13$ & 13 & 14 & 15 & 11 & 14 & 11 \\
\hline Kozhernikovo & 65 & 250 & 15 & 15 & 15 & 15 & 15 & 14 & 15 & 15 \\
\hline Permomaiskoe & 100 & 45 & 9 & $9-10$ & 9 & 10 & 9 & 9 & 10 & 11 \\
\hline Krasnyi Yar & 70 & 335 & 7 & 6-7 & 8 & 9 & 6 & 6 & 7 & 7 \\
\hline Baturino & 130 & 5 & 11 & $7-12$ & 11 & 12 & 10 & 12 & 13 & 14 \\
\hline Bolotnoe & 105 & 205 & 10 & 10 & 11 & 11 & 10 & 12 & 11 & 10 \\
\hline $\begin{array}{c}\text { Tomsk } \\
\text { aeronau. } \\
\text { station }\end{array}$ & 30 & 120 & 14 & $13-14$ & 13 & 13 & 12 & 11 & 12 & 10 \\
\hline $\begin{array}{c}\text { Tomsk } \\
\text { hydromet. } \\
\text { station }\end{array}$ & 20 & 220 & 9 & 8-9 & 9 & 10 & 11 & 12 & 12 & 10 \\
\hline Belyi Yar & 205 & 0 & 12 & $12-13$ & & 9 & 9 & 10 & 11 & 11 \\
\hline
\end{tabular}

limits of fluctuation of the radioactive background. These increases were of no significance, as precipitations and concentrations of the same amounts had also been observed on some days in March. No radioactivity changes wore recorded at the Norilsk station located north of Turukhansk. This means that radioactive contamination had a purely local character. The data measured until April 30, 1993 allow the conclusion to be drawn that no radioactive products were entrained beyond the national borders.

Environmental monitoring after the accident was not only accomplished by the measuring stations, but also by the ZapSibgidromet experts who investigated the area directly near the site of the accident [2]. On April 7, measurements were carried out in the villages of Georgievka and Naumovka with a view to determine the end of the radioactive trace and the extent of contamination. On the next days, measuremessts were performed along nine footpaths in transverse direction to the trace and along it as well as along the fence surrounding the premises of the chemical combine. Between $\mathrm{km} 20$ and $\mathrm{km} 31$ of the road from Tomsk to Samus, the gamma background was measured on the untouched snow at a distance of 10 to $50 \mathrm{~m}$ from the road. The following gamma exposure rates were recorded:

Road section Gamma exposure rate, $\mu \mathrm{R} / \mathrm{h}$

$\mathrm{Km} 20-28$

$12-30$

$\mathrm{Km} 28-28.6$

$30-510$

$\mathrm{Km} 28.6-28.9$

$510-180$

$\mathrm{Km} \mathrm{28.9-29.6}$

180-200

Kin 29.6-31.1

200-20 
Table 9.2. Gomma exposure rate measured by the measuring stations of the radiometrical network of the Krasnoyarskgidromet after the accident at the chemical combine, $\mu R / h$.

\begin{tabular}{|lcc|}
\hline Measuring station & April 6-1, 1993 & March 1993 \\
\hline \hline Bolshaya Murta & 11 & 10 \\
Sukhobuzimskoe & 12 & 11 \\
Dzerzhinskoe & 19 & 17 \\
Kemchug & 10 & 11 \\
Shumikha & 11 & 10 \\
Krasnoyarsk & 11 & 11 \\
Uyar & 12 & 12 \\
Shalinskoe & 10 & 10 \\
Balakhta & 16 & 10 \\
Kacha & 10 & 10 \\
Nazarovo & 19 & 18 \\
Stelka & 12 & 13 \\
Podkamennaya Tunguska & 17 & 13 \\
Yeniseisk & 9 & 17 \\
Achinsk & 21 & 11 \\
Turukhansk & 19 & 19 \\
Motygino & 13 & 13 \\
Vanavara & 15 & 12 \\
Yartsevo & 15 & 17 \\
\hline
\end{tabular}

From these data, the high radioactive contamination between $\mathrm{km} 28$ and $\mathrm{km} 31$ is clearly visible. Therefore, workers of the chemical combine carried out decontamination at $\mathrm{km} 29$ of the road. Thus, the gamma exposure rates in the most contaminated sections could be reduced to $120 \mu \mathrm{R} / \mathrm{h}$. Along the fence around the combine premises, the gamma exposure rate ranged between 225 and $12 \mu \mathrm{R} / \mathrm{h}$ from $\mathrm{km} 28.5$ to 30.5 . At the guard houss at the entry of the combine, a value of $12 \mu \mathrm{R} / \mathrm{h}$ was measured. At $\mathrm{km} 28.5$ of the road, gamma backgroind measurement was performed up to a distance of $700 \mathrm{~m}$ from the road in the direction towards the combine. Gamma exposure rate varied between 180 and $480 \mu \mathrm{R} / \mathrm{h}$. Starting at this road section, measurements were made every $500 \mathrm{~m}$ until the village of Georgievka was reached. The results obtained are presented below:

Distance, $\mathrm{m}$ Gamma exposure rate, $\mu \mathrm{R} / \mathrm{h}$

$\begin{array}{cc}0-500 & \text { up to } 270 \\ 500-1000 & 270-180 \\ 1000-1500 & 180-216 \\ 1500-2000 & 216-240 \\ 2000-2500 & 240-200 \\ 2500-3000 & 200-160 \\ 3000-3500 & 160-350 \\ 3500-4000 & 350-310 \\ 4000-4500 & 310-280\end{array}$


Of all villages located in the $30-\mathrm{km}$ zone, only Georgievka suffered from contamination. The values measured there are indicated below. At the remaining 14 places (Malinovka, Aleksandrovskoe, kolkhoz "Rassvet", Kopylovo, Kuzovlevo, Bobrovka, Mikhailovka, Nadezhda, Dzerzhinski, Timiryazevo, Zerkaltsevo, Berezovka, Porosino and Nelyubino), gamma dose rate amounted to $7-14 \mu R / h$ be. tween April 6 and 12, 1993. At the villages of Karakozovo, Tyulalovo, Yegorovo and Karyukina, a value smaller than $10 \mu \mathrm{R} / \mathrm{h}$ was determined. At Tomsk-7 and Tomsk, the gamma dose rate was $12 \mu \mathrm{R} / \mathrm{h}$ which corresponded to the natural gamma background. On the route from Naumovka to Georgievka, the gamma radiation field was found to have a spot-like structure:
$3.0 \mathrm{~km}$ away from Naumovka,
$3 \mathrm{~m}$ away from road
$150-160 \mu \mathrm{R} / \mathrm{h}$
$30 \mu \mathrm{R} / \mathrm{h}$
3.5 im away from Naumovka
$50-100 \mathrm{~m}$ away from road
$17-30 \mu \mathrm{h} / \mathrm{h}$
$1.0 \mathrm{~km}$ away from Georgievka, on the road surface
$70 \mu \mathrm{R} / \mathrm{h}$

Alter the accident, gamma exposure rate at Georgievka increased in $28-42 \mu \mathrm{R} / \mathrm{h}$. At certain points on the northern fringe of the village, even values oi up to $60 \mu \mathrm{R} / \mathrm{h}$ were recorded. The values measured at Georgievlia are represented in Fig. 3.1. Here, the gamma exposure rates are given in $\mu \mathrm{R} / \mathrm{h}$ for certain points of the village. A mean dose rate of $27 \mu \mathrm{R} / \mathrm{h}$ was attained. The gamma exposure rates on the streets were smaller, while on the untouched snow in the surroundings they were found to be very much higher. Here, values of $40 \mu \mathrm{R} / \mathrm{h}$ were attained. In the fields outside of Georgievka, a value of $30 \mu \mathrm{R} / \mathrm{h}$ was measured. The measurements on the surface of the ground thus revealed that radioactive contamination of the ground was extremely leterogeneous. This was attributed above all to the existence of hot particles in the aerosol products deposited on the snow.

The results of radioisotopic analysis of two snow samples taken at Georgievka six days after the accident (April 12, 1993) are obvious from table 3.3. According to these data, contamination at Georgievka was mainly caused by ${ }^{95} \mathrm{Nb}$ and ${ }^{106} \mathrm{Ru}$, while ${ }^{95} \mathrm{Zr}$ was of minor importance. Contamination by ${ }^{103} \mathrm{Ru}$ could be neglected. All these isotopes are relatively short-lived and, hence, did not appear when determiniing the composition of the gross radioactive background. They merely represented accident products. Background contamination by ${ }^{90} \mathrm{Sr}$ of global origin amounted to about $0.03 \mathrm{Ci} / \mathrm{km}^{2}$.

Therefore, concentration of this isotope in the snow could also be neglected. It must be pointed out that ${ }^{90} \mathrm{Sr}$ was almost exclusively contained in the aqueous fraction, while the gamma-emitting isotopes were bound to the suspended fractions. 'iotal density of radioactive contamination at Georgievka was $1.6 \mathrm{Ci} / \mathrm{km}^{2}$.

The contamination densities of the individual isotopes in the Georgievka area were calculated at a mean gamma dose rate of the entire village of $N_{\text {ro }} 0=27$ $\mu \mathrm{R} / \mathrm{h}$. They are given in the tottom line of table 3.3. The formulas applied for the calculation are presented in Annex 1 . The calculations are hased on the assumption of a natural gamma backr, round of $N_{\gamma o}=10 \mu \mathrm{R} / \mathrm{h}$. The calculated results are in good agreement with the measured values. Contamination of Georgievka by plutonium $\left(0.1 \mathrm{mCi} / \mathrm{km}^{2}\right)$ can hence be neglected.

On the basis of the data given in table 3.3, external gamma irradiation of the local population may be approximated. For this purpose, it is assumed that no migration of the population takes place. Shielding of the gamma radiation by the walls of the houses and production facilities is neglected. The film contamination of the ground (upper dose value) was calculated using the dose coefficients given in Annex 1 and taking into account the natural isotope migration into the ground.

Risø-R-750(EN) 


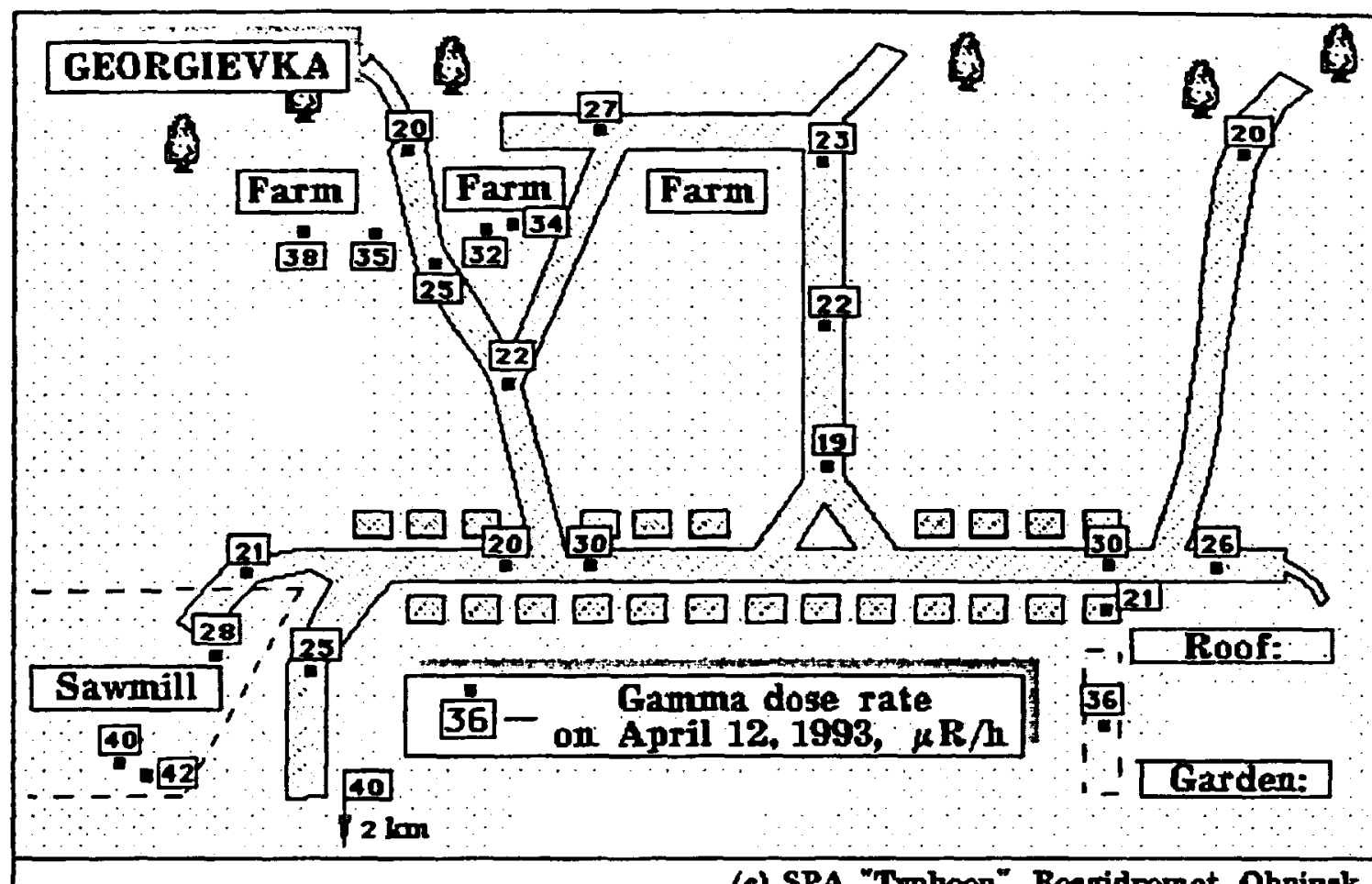

(c) SPA "Typhoon", Rasgidromet, Obninsk

Figure 3.1. Gamma dose rates at Georgievka on April 12, 1993, $\mu R / h$.

Table 3.3. Density of snow contamination by individual radianuclides at Georgievka on April 12, 1993, Ci/km².

\begin{tabular}{|c|c|c|c|c|c|c|c|c|}
\hline $\begin{array}{l}\text { Sampling } \\
\text { point }\end{array}$ & $\begin{array}{l}\text { Analyzed } \\
\text { fraction of } \\
\text { the sample }\end{array}$ & ${ }^{103} \mathrm{Ru}$ & ${ }^{106} \mathrm{Ru}$ & ${ }^{95} \mathrm{Zr}$ & ${ }^{95} \mathrm{Nb}$ & ${ }^{90} \mathrm{Sr}$ & ${ }^{239} \mathrm{Pu}$ & $\Sigma_{\gamma}$ \\
\hline \multirow{3}{*}{$\begin{array}{l}\text { House No. } 6 \\
\text { front yard }\end{array}$} & auspension & 0.023 & 0.566 & 0.432 & 0.919 & 0.0000 & $0.12 \times 10^{-3}$ & \\
\hline & water & 0.000 & 0.100 & 0.046 & 0.107 & 0.0006 & & \\
\hline & total & 0.023 & 0.666 & 0.478 & 1.030 & 0.0006 & $0.12 \times 10^{-3}$ & \\
\hline \multirow{3}{*}{$\begin{array}{l}\text { Fringe of } \\
\text { the village } \\
\text { field path }\end{array}$} & suspension & 0.019 & 0.403 & 0.224 & 0.358 & & & \\
\hline & water & 0.000 & 0.032 & 0.013 & 0.027 & & & \\
\hline & total & 0.019 & 0.435 & 0.237 & 0.385 & & & \\
\hline \multirow{2}{*}{$\begin{array}{l}\text { Mean values } \\
\text { calculated } \\
\text { according to } \\
\text { Eqs. (7) \& (12) } \\
\text { Annex }\end{array}$} & total & 0.021 & 0.55 & 0.36 & 071 & 00006 & $0.12 \times 10^{-3}$ & 1.6 \\
\hline & total & 0.024 & 0.54 & 0.37 & 0.80 & & $0.13 \times 10^{-3}$ & 1.7 \\
\hline
\end{tabular}


The calculations are obvious from table 3.4 [6]. Reduction of the radiation dose due to the penetration of the isotopes into the soil when digging the gardens and ploughing the fields was not taken into consideration.

Table 9.4. External gamma irrediation of the Georgierka population by the radicective products released during the accident and the natural gamme background over the period indicated, $10^{-3} \mathrm{rem}$.

\begin{tabular}{|c|ccccc|}
\hline $\begin{array}{c}\text { Time, } \\
\text { years }\end{array}$ & Ru-103 & Ru-106 & $\begin{array}{c}\text { Zr-95+ } \\
\text { Nb-95 }\end{array}$ & Total & $\begin{array}{c}\text { Nat. gamma } \\
\text { background }\end{array}$ \\
\hline 1 & $0.15-0.16$ & $6.6-8.3$ & $12-14$ & $19-32$ & 70 \\
2 & $0.15-0.16$ & $8.6-13$ & $12-14$ & $21-27$ & 140 \\
3 & $0.15-0.16$ & $10-17$ & $12-14$ & & 3500 \\
\hline
\end{tabular}

It is evident from the data above that external gamma irradiation of the population is less than $1 \%$ of the irradiation resulting from the natural gamma background even when staying permanently (for a period of 50 years) at Georgievka. The calculations were based on the assumptions of $N_{\gamma_{0}}=10 \mu \mathrm{R} / \mathrm{.}$ and $1 \mathrm{R}=$ $0.8 \mathrm{rem}(\mathrm{cSv})=0.87 \mathrm{rad}(\mathrm{cGy})$ for air. External irradiation with ${ }^{103} \mathrm{Ru},{ }^{95} \mathrm{Zr}$ and ${ }^{95} \mathrm{Nb}$ becomes obvious within a period of one year after the accident. Irradiation with the longer-lived ${ }^{106} \mathrm{Ru}$ is steadily increasing. The shares of gamma irradiation of ${ }^{106} \mathrm{Ru}$ and ${ }^{95} \mathrm{Zr}+{ }^{95} \mathrm{Nb}$ in the external irradiation are nearly the same, the contribution of ${ }^{103} \mathrm{Ru}$ can be neglected. It may therefore be concluded that external gamma irradiation does not represent any danger to the Georgievka population.

\section{Prognosis of Contamination Resulting from Secondary Wind Transport}

Judging from the geographical data of the contaminated area, about $10 \%$ of the territory is under agricultural use. This territory may be a source of air contamination, when the radionuclides deposited on the fields are transported by the wind. The greatest risk to the population consists in the intake of Pu-239 by inhalation. It therefore seems to be reasonable to estimate air contamination in the area under agricultural use. Air contamination may result from wind or mechanical transport of the deposited sadionuclides. Mechanical transport takes place when the soil is cultivated using agricultural equipment or when traffic is passing. Now, air contamination resulting from wind erosion and mechanical impacts shall be estimated. According to the data obtained in the Chernobyl area [7], the intensity of wind transport of recently deposited radionuclides amounts to $10^{-9} \mathrm{~m}^{-1}$. Assuming that the area under agricultural use is $\sim 10 \mathrm{~km}^{2}$ with the height of the layer near to the ground surface being $50 \mathrm{zm}$ and the contamination density by gamma and beta emitters $\sim 5 \mathrm{Ci} / \mathrm{km}^{2}$ (Georgievka), a maximum concentration of these emitters in the air near the ground surface of $5 \times 10^{-16} \mathrm{Ci} / \mathrm{l}$ is obtained. This value is smaller than the corresponding dose coefficients $D_{B}$ of these radionuclides by four to five orders of magnitude. In our case, air contamination by Pu-239 was $6 \times 10-20 \mathrm{Ci} / 1\left(\mathrm{DK}_{\mathrm{B}}=3 \times 10^{-17} \mathrm{Ci} / \mathrm{l}\right)$. This value was calculated at a contamination density of $8 \times 10^{-4} \mathrm{Ci} / \mathrm{km}^{2}$. It allowed the conclusion to be drawn that contamination of the air due to wind transport of the radionuclide; was insignificant and did not represent alyy danger to the population. Mechanical impacts may considerably intensify the wind transport of the radionuclides. The 
maximum values measured for the intensity of wind transport of $\mathrm{Pu}-239$ are $10^{-4}$ $s^{-1}$ and $10^{-6} s^{-1}$ for passing traffic and ploughing of the fields, respectively [8].

Let us now assume that maximum air contamination is caused by public and agricultural traffic passing in transverse direction to the wind. Thus, a stationary active source is generated, the intensity of which may be estimated as follows:

$$
Q=I \text { rap, }
$$

where

$$
\begin{aligned}
I= & \text { traffic density, } \mathrm{s}^{-1} ; \\
\boldsymbol{I}= & \text { minimum time interval between the individual clouds } \\
& \text { generated by the traffic; } \\
& \text { it is calculated using the continuity condition of a jet; } \\
a= & \text { intensity of wind transport of the radionuclides, } \mathrm{s}^{-1} ; \\
\rho_{s}= & \text { ground contamination density, } \mathrm{Ci} / \mathrm{km}^{2} .
\end{aligned}
$$

The time $\tau$ was calculated using the following equation:

$$
\ln \left(b u_{*} \tau / e z_{0}\right)=\kappa \alpha_{x x}
$$

where

$$
\begin{aligned}
& b \quad \sim \quad 0.3 \text { is the universal constant in the similarity theory } \\
& \text { of the Lagrangean turbulence characteristics; } \\
& u_{*}=\text { dynamic velocity, } \mathrm{m} / \mathrm{s} ; \\
& z_{0}=\text { roughness parameter, } \mathrm{m} ; \\
& \boldsymbol{e} \quad=\text { von Kármán constant; } \\
& \boldsymbol{\alpha}_{x x}=\text { base of natural logarithm; } \\
& \text { scattering parameter of the impurity. }
\end{aligned}
$$

In the calculations, a value of $\tau \sim 9 s$ was obtained at $u_{*}=0.2$ and $z_{0}=0.1$ $m$. With the traffic density being 10 vehicles per hour and the width of the road $10 \mathrm{~m}$, efficiency of the linear source amounts to

$$
Q=2 \times 10^{-13} \mathrm{Ci} / \mathrm{m} \times 8 .
$$

At a distance of $100 \mathrm{~m}$ from the road, Pu-239 concentration then is $2 \times 10^{-18}$ $\mathrm{Ci} / l$. For comparison with $\mathrm{DK}_{\mathrm{B}}$, this value must be converted into the mean annual concentration. For this purpose, it is now assumed that the dry season, during which the risk of wind transport exists, lasts three months and that traffic is continuous over a period of eight hours a day. Then, a mean annual concentration of $1.5 \times 10^{-19} \mathrm{Ci} / /\left(\mathrm{DK}_{\mathrm{B}}=3 \times 10^{-17} \mathrm{Ci} / l\right)$ is obtained.

As far as the mean effective equivalent dose was concerned, a value of $0.3 \mathrm{rem}$ was calculated for a period of 50 years. Hence, it did not represent any danger to the population. Estimation of the influence of mechanical cultivation of the soil on the wind transport yields concentration values that are smaller than the above values by two orders of magnitude.

On the basis of the investigations performed, it must be noted that wind transport of the radionuclides does not lead to a dangerous radiation exposure of the population. 


\section{Prognosis of Water Contamination}

\subsection{Estimated Radionuclide Concentration of the Samuska River}

Following the accident at the chemical combine, also part of the catchment of Samusla river, a subsidiary stream of the Tom river, was exposed to the a adioactive fallout. The area covered by the trace was about $100 \mathrm{~km}^{2}$. According to the analyses carried out by the experts of SPA "Typhoon", the gamma dose was mainly caused by Ru-103, Ru-106, Zr-95 and Nb-95. As far as the alpha emitters were concerned, $\mathrm{Pu}-239$ was of major importance. Total activity outside of the controlled area of the combine was estimated to range from 300 to $500 \mathrm{Ci}$. A significant part of the fallout was found to occur in the controlled area. According to the estimations, the total activity released amounted to about 800 to $1000 \mathrm{Ci}$. For the calculations, a value of $1000 \mathrm{Ci}$ can be used. Then, the activities of the individual radionuclides are as follows:

$\begin{array}{ccc}\text { Ru-103 } & - & 10 \mathrm{Ci} \\ \mathbf{R u}-106 & - & 300 \mathrm{Ci} \\ \mathbf{Z r}-95 & - & 210 \mathrm{Ci} \\ \mathbf{N b}-95 & - & 470 \mathrm{Ci} \\ \text { Pu-239 } & -0.1-0.2 \mathrm{Ci}\end{array}$

(Pu-239 fallout was estimated on the basis of the equation:

$\left.[\mathrm{Pu}-239] /[\mathrm{Zr}-95]=10^{-3}-3.5 \times 10^{-4}\right)$.

\subsection{Contamination of the flood in spring}

The fallout mainly deposited on the snow. Therefore, considerable washout of the radionuclides was expected to take place in the Samuska and Tom rivers when the snow would be melting. The parameters of the flood in spring, which were predicted by the ZapSibgidromet experts, are obvious from table 5.1. 
Table 5.1. Parameters predicted for the flooding of the Samuste end Tom rivers in spring 1993.

\begin{tabular}{|c|cccccc|}
\hline River & $\begin{array}{c}\text { catchment } \\
\text { area } \\
\mathrm{km}^{2}\end{array}$ & $\begin{array}{c}\text { Surface } \\
\text { runof } \\
\mathrm{mm}\end{array}$ & $\begin{array}{c}\text { Flow volume } \\
\text { during flood } \\
\mathrm{km}^{3}\end{array}$ & $\begin{array}{c}\text { Mean flow } \\
\text { rate } \\
\mathrm{m}^{3} / \mathrm{s}\end{array}$ & $\begin{array}{c}\text { Mean } \\
\text { turbidity } \\
\mathrm{g} / \mathrm{m}^{3}\end{array}$ & $\begin{array}{c}\text { Specific flom } \\
\text { of sediment } \\
\mathrm{t} / \mathrm{km}^{2}\end{array}$ \\
\hline $\begin{array}{c}\text { Tom, Tomsk } \\
\text { station }\end{array}$ & 57000 & 246 & 14 & 2780 & 70 & \\
$\begin{array}{c}\text { Samuska } \\
\text { mouth }\end{array}$ & 505 & 108 & 0.054 & 42 & 28 & 0.56 \\
$\begin{array}{c}\text { Station near } \\
\text { the combine }\end{array}$ & 333 & & & & & \\
\hline
\end{tabular}

\subsection{Estimation of radionuclide washout}

Prognosis of the radionuclide flow was based on the homogeneous distribution of the radionuclides in the snow water. While flowing, the radionuclides interact with the earth layer and sorption takes place. According to [9], this interaction layer is about $1 \mathrm{~cm}$ thick. It is assumed that a sorption equilibrium exists between the earth and the water flow. This equilibrium is characterized by the distribution coefficient $K_{d}$. Only little is known about the distribution coefficients of Ru-103, Ru-106, Zr-95 and Nb-95. According to the data published in [10], however, the behavior of Ru-106 in the soil practically corresponds to that of Cs-137. It was therefore expected that the migration processes of these radionuclides were similar as well. It was shown in [11] that the distribution coefficient of the radionuclides depends on the water/soil volume ratio. Under the flow conditions outlined in table 5.2, this ratio is about 10 . This corresponds to a distribution coefficient of $K_{d} \sim 200$. According to [7], the distribution coefficient of Pu-239 is in the range of $10^{3}-10^{4}$. For maximization of the estimations, the former value was selected. The washout factors were calculated ir: accordance with the method described in [12, 13]. It was found out that the washout factors of the dissolved phase amounted to about $5 \%$ and $1 \%$ for gamma and beta emitting radionuclides and for Pu-239, respectively. In the solid phase, the washout factor does not exceed $0.3 \%$ for all radionuclides. It must be pointed out that the estimated washout factors were too high by an order of magnitude at least. This was due to the assumption that all radionuclides were present in the exchange form. It is known, however, that the exchange form is $1-5 \%$ of the irreversibly sorbed form only [11].

Table 5.2. Mean radionuclide concentration of the rivers Tom and Samuska.

\begin{tabular}{|c|ccccc|}
\hline \multirow{2}{*}{ River } & \multicolumn{5}{|c|}{ Radionuclide concentration of the water, $\mathrm{pCi} / \mathrm{l}$} \\
\cline { 2 - 7 } & $\mathrm{Ru}-103$ & $\mathrm{Ru}-106$ & $\mathrm{Zr}-95$ & $\mathrm{Nb}-95$ & $\mathrm{Pu}-239$ \\
\hline \hline Tom & 0.04 & 1.0 & 0.7 & 1.6 & 0.001 \\
Samuska & 10 & 150 & 120 & 300 & 0.2 \\
\hline DK $_{\mathrm{B}}$, water & 80000 & 12000 & 62000 & 96000 & 2900 \\
\hline
\end{tabular}

The calculated mean concentrations of the flood are presented in table 5.2. Comparison of the calculated mean values and the permissible concentrations (bottom line in table 4.2) shows that the concentrations in the water are smaller than DKB 
by a fector of $10^{2}-10^{4}$ eren under the most unfarorable washout conditions. It must be taken into consideration that the limit value DKB was calculated for the annual standardized water consumption with the internal irradiation being $5 \times$ $10-3 \mathrm{Sr}$.

\section{Supply of Information for the Estimation of Radiation Exposure in the Area of the Siberian Chemical Combine}

Supply of information for the analysis of radiation exposure in the area affected by the accident depended on the data available and could be divided into two stages:

A. Analysis of the situation, estimation of the release parameters and determination of preliminary data on the possibly contaminaled area and the radiation exposure, estimation of a possible transport beyond the national borders. In this stage, data measured at ground level were not yet available. Therefore, numerous calculations were carried out on the basis of a physico-mathematical simulation of radioactivity spread in the environment using preliminary findings about the source.

B. Systematization of the data with the aim of setting up a diagram of radioactive contamination of the environment soon after the accident as a function of time and space.

It is the objective of this stage to estimate the statistical reliability of all values measured when investigating the contaminated area and to malie use of these data when determining (more precisely) the radionuclide composition of the emissions and their quantitative ratio. Furthermore, a map of contamination in this area shall be prepared (gamma dose rate at ground level, contamination densities of all radionuclides identified in the samples).

As ground measurements were carried out outside of the premises of the chemical combine only, calculations were performed for the entire contaminated area including the combine site. Radioactivity spread in the area as a function of space and time then allowed to estimate the possible individual doses when passing the radioactive cloud.

\subsection{Information for the taking of appropriate measures dur- ing the first hours after the accident}

On April 6, 1993 at about 17.00 incal time, SPA "Typhoon" was informed by Rosgidromet about the accident at the chemical combine. For information, Rosgidromet also transmitted the following data on the release:

- Nuclide composition: Pu-239, U-238;

- total activity released: 2 - $5 \mathrm{Ci}$;

- activity released into the environment via the destroyed walls of the buildings (height of release up to $30 \mathrm{~m}$ );

- duration of the release about 15 min.

On the basis of weather forecasts, possible trajectories were determined for the movement of the radioactive cloud at various heights (ground level, $700-800 \mathrm{~m}$ and about $1500 \mathrm{~m}$ ). They are represented in Fig. 6.1. 


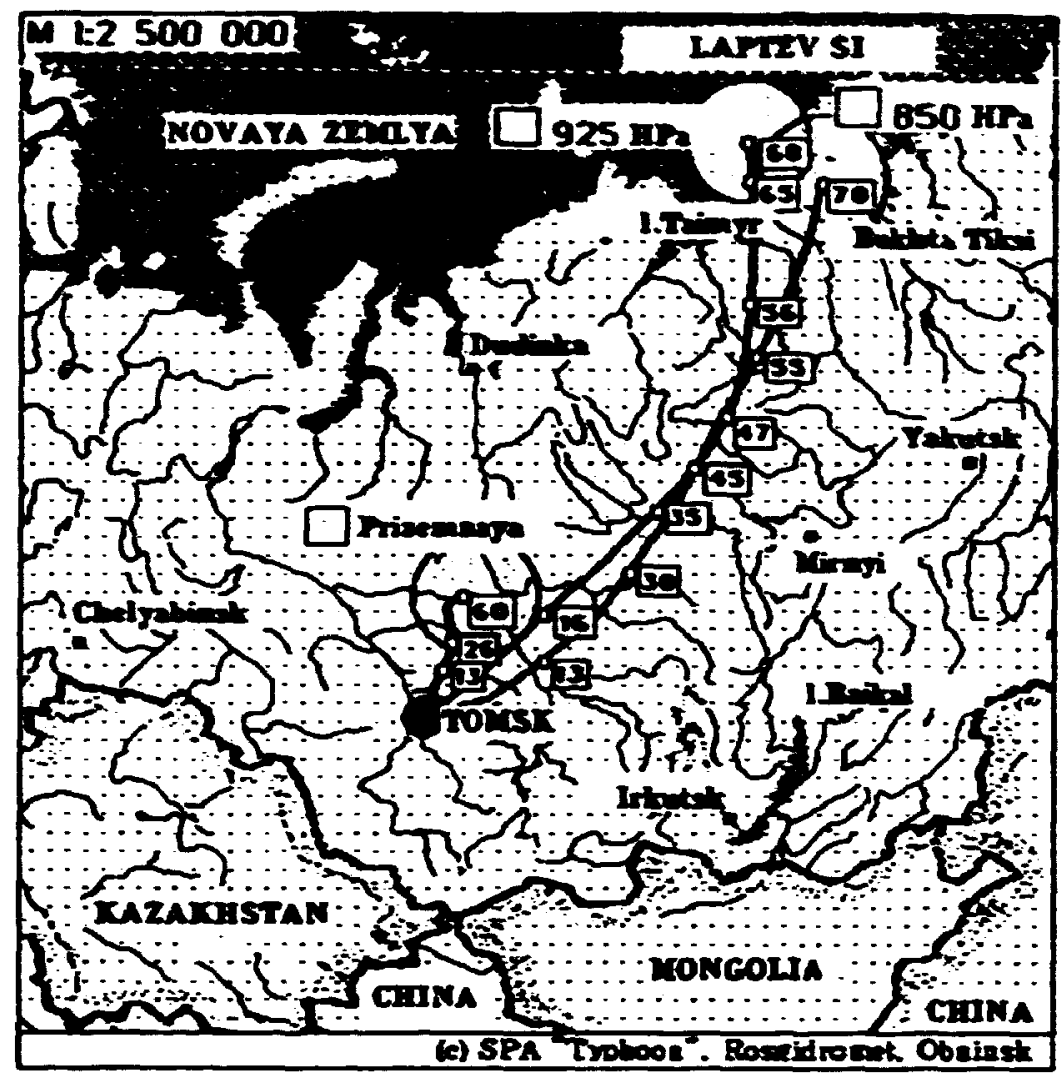

Figere 6.I.

By simulating the atmospheric transport of Pu-239. radioactivity conce-itration of the cloud was found to have been decreased to insignificant values due to diffusion and deposition processes within a period of 3.5 hours after the accident. According to the simulation data, maximum Pu-239 concent ration of the cloud 3.5 hours after the accident amounted to $1.5 \mathrm{E}-1 \mathrm{Ci} / \mathrm{l}$ (permissible concentration $3.0 \mathrm{E}-1 \mathrm{i} \mathrm{CH} / \mathrm{l})$ at a distance of $110 \mathrm{~km}$ from the source and a height of $1 \mathrm{~m}$. Thus. transport of significant radionuclide concentrations (exceeding DKB) beyond the national borders could be excluded.

The values of ground contamination by Pu-239, which were oblained by sinulating the at mospheric transport and deposition of the radioactivity, are represented in Fig. 6.3. The ganma aerial survey data oblained later confirmed that the predictions based on the simulation had been very precise.

For simulation, the "Gaussian club" model developed by the data processing center of SPA "Typhoon" according to the method described in [14] was applied. Simulation was performed for a source with a height of $30 \mathrm{~m}$ (building, where the accident occurred), a release duration of 15 min. and a total Pu-230 activity released of $5 \mathrm{Ci}$.

After the receipt of the message, an "express" analysis of the accident was carried out by SPA "Typhoon". The results wete then processed and transmitled to Rosgidromet at 20.00 Moscow time on April 6, 1093.

The first data on the radiation exposure were received by SPA "Typhoon" on April $i$ and 8, 1993. Gamma dose rales at ground level near the building affected (30 $\mu R / h)$, at kin 28 of the road from Tomsk to Sanus aud at Naumovka $(14 \mu R / h)$ and Georgievka $(40-60 \mu \mathrm{R} / \mathrm{h}$ ) were measured by expert teams of ZapSibgidromet and Rosgidromet. On the basis of the first analyses of snow samples, radionuclide 
composition of the netease coold be determined more accurately:

Nb-95 - 35x; Ru-105 - 35x; Ru-103 - 1\%; 2r-95 - $23 x$.

The following main source parameters were determined more precisely and reeomanended for simulation by the Rocidromat experis:

- Retease beight 15 - 150 in (the source was simulated by two simultaneous relewes at beights of $15-30 \mathrm{~m}$ (50x of the tolal activity) and $150-200 \mathrm{~m}$ (sos of the total activity), respectively);

- depasitioa rale $0.01-0.19 \mathrm{~m} / \mathrm{s}$;

- duration of the release 10 - 15 min.;

- total activity rekeased 150 - $400 \mathrm{C}$.

On the basis of the data recommended by the Rospidromet experts, contamiantion deasity of the most important radionuclides was calculated. The map plocted

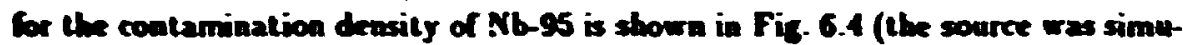
lated by two simultancous releases from the bailding afected (release beight $30 \mathrm{~m}$, $50 \%$ of the total activity) and the rentilation pipe (beighe $200 \mathrm{~m}, 50 \times$ of the total activity), respectively, al a deposition rate of the radioactive products of $0.15 \mathrm{~m} / \mathrm{s}$ and an asouned tolal Nb-95 activity reteaned of $400 \mathrm{CT}$ ).

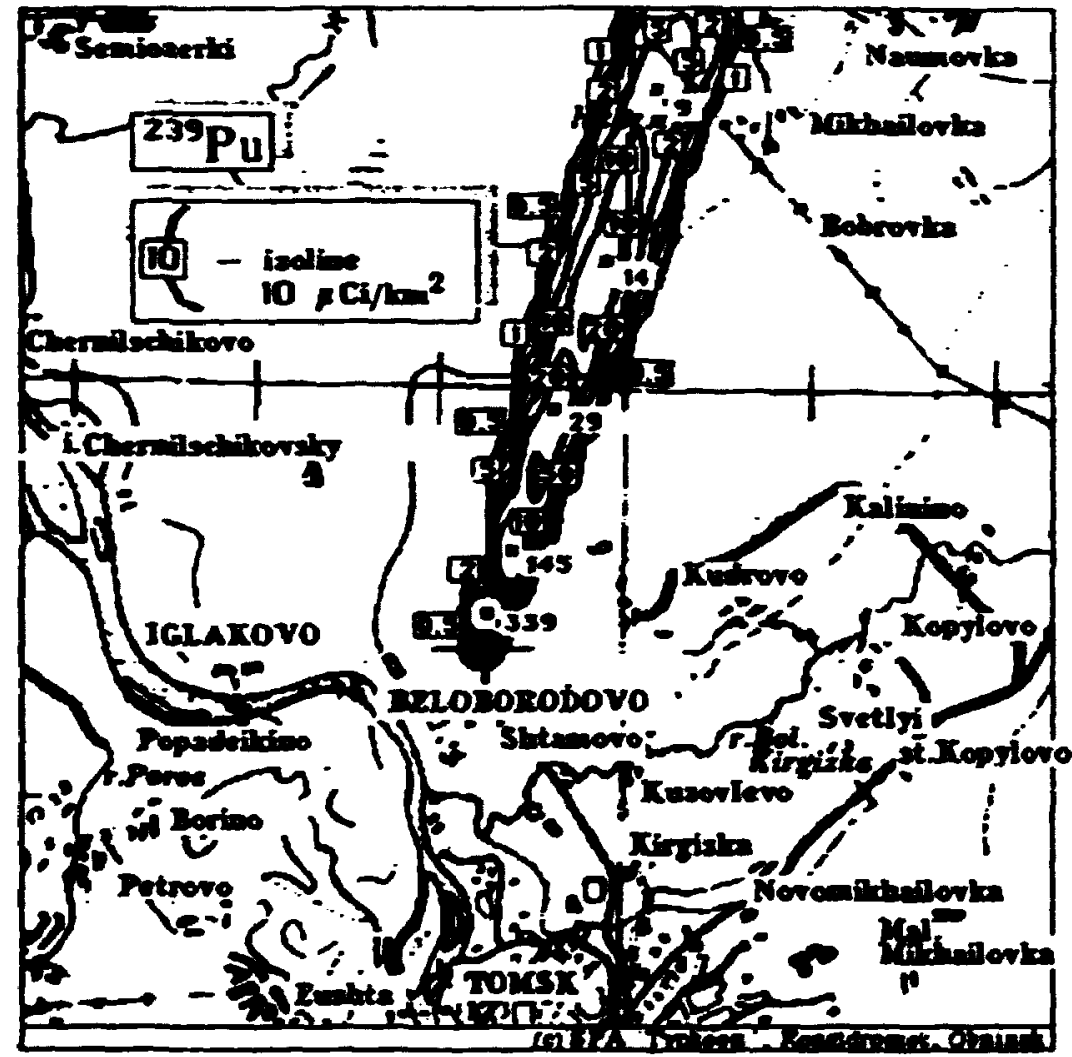

Figere 6.2. 


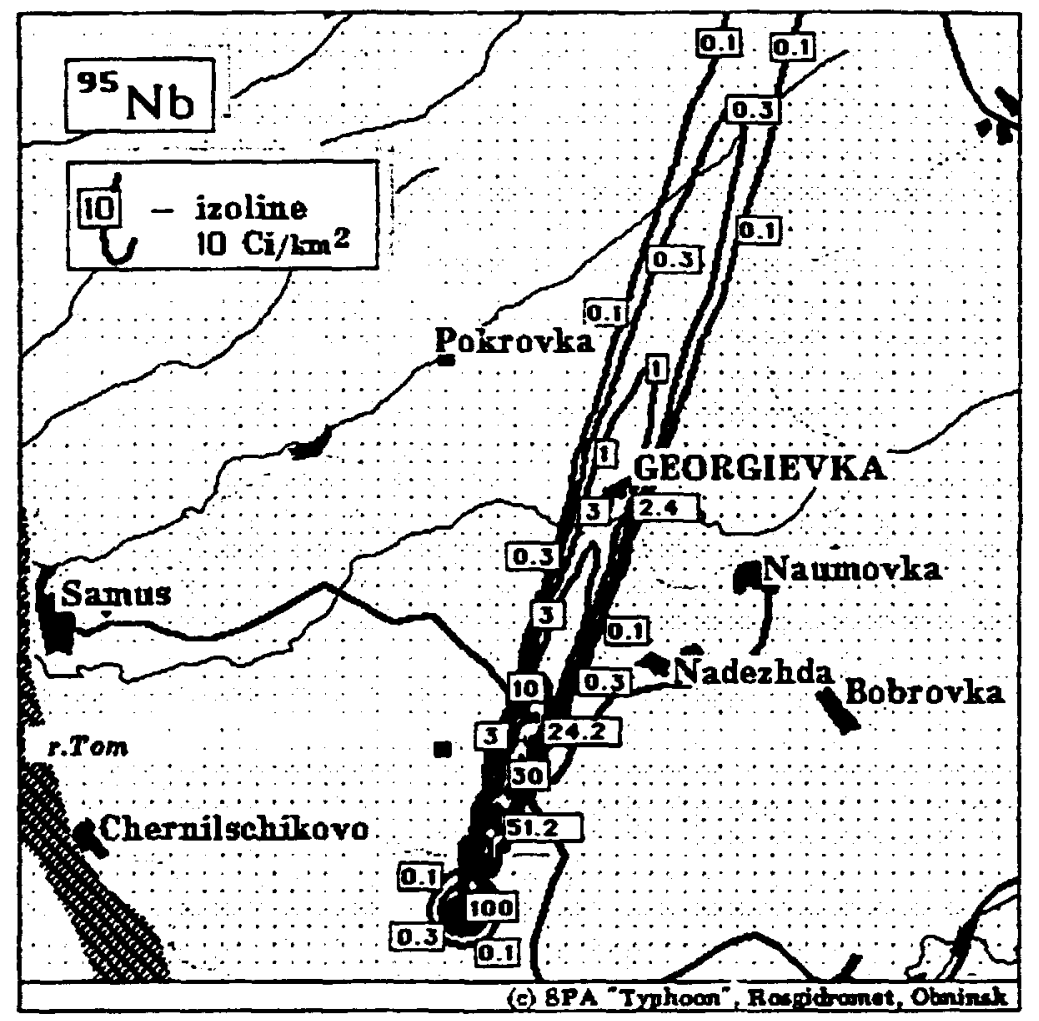

Figure 6.9.

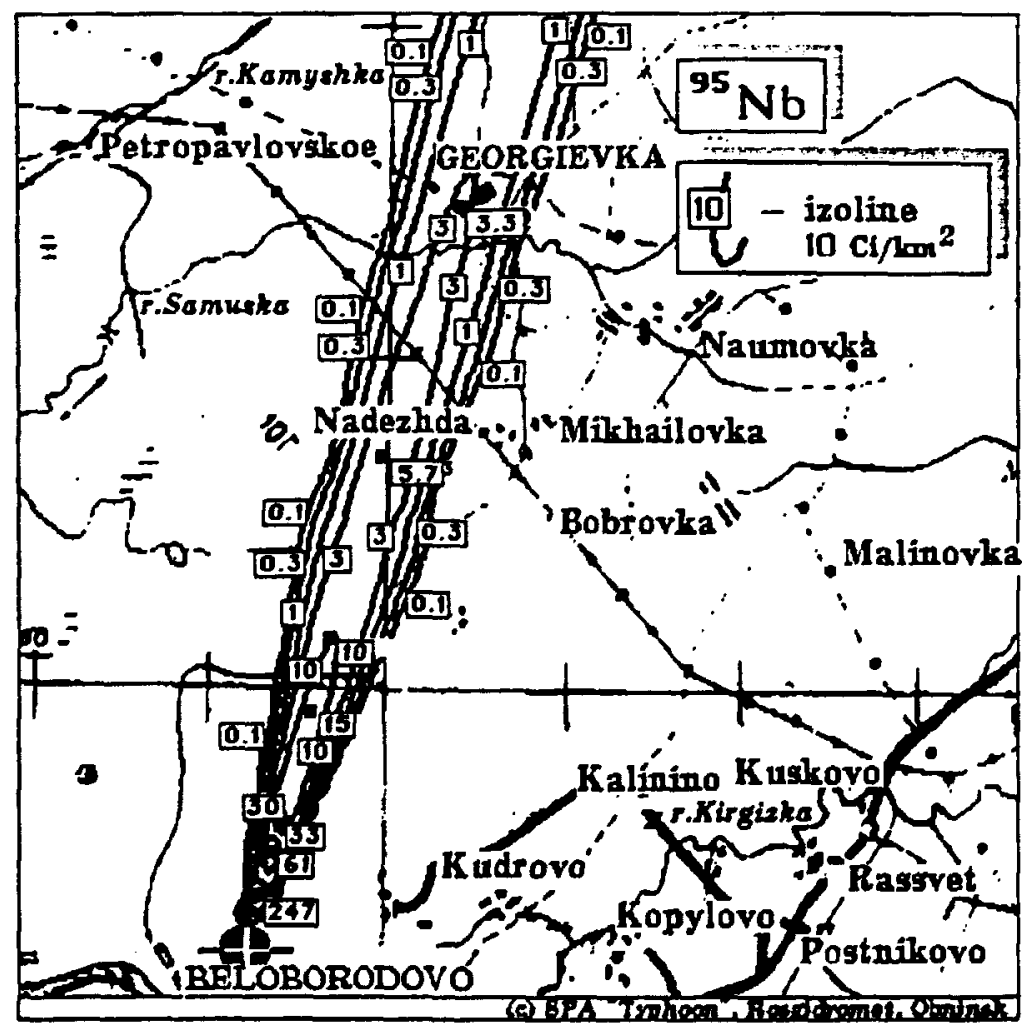

Figure 6.4. 


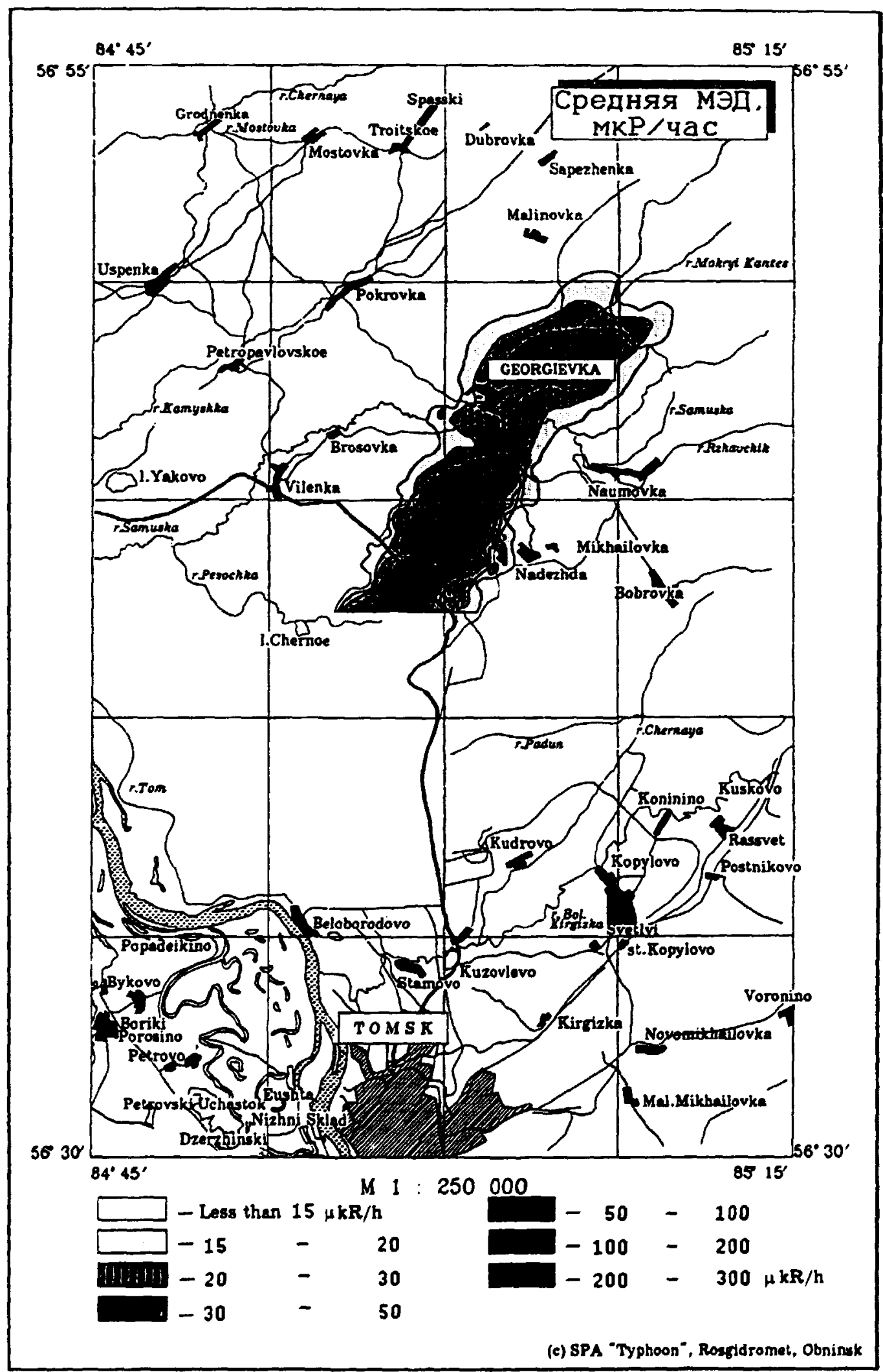

Figure 6.5.

Riso-R-750(EN) 


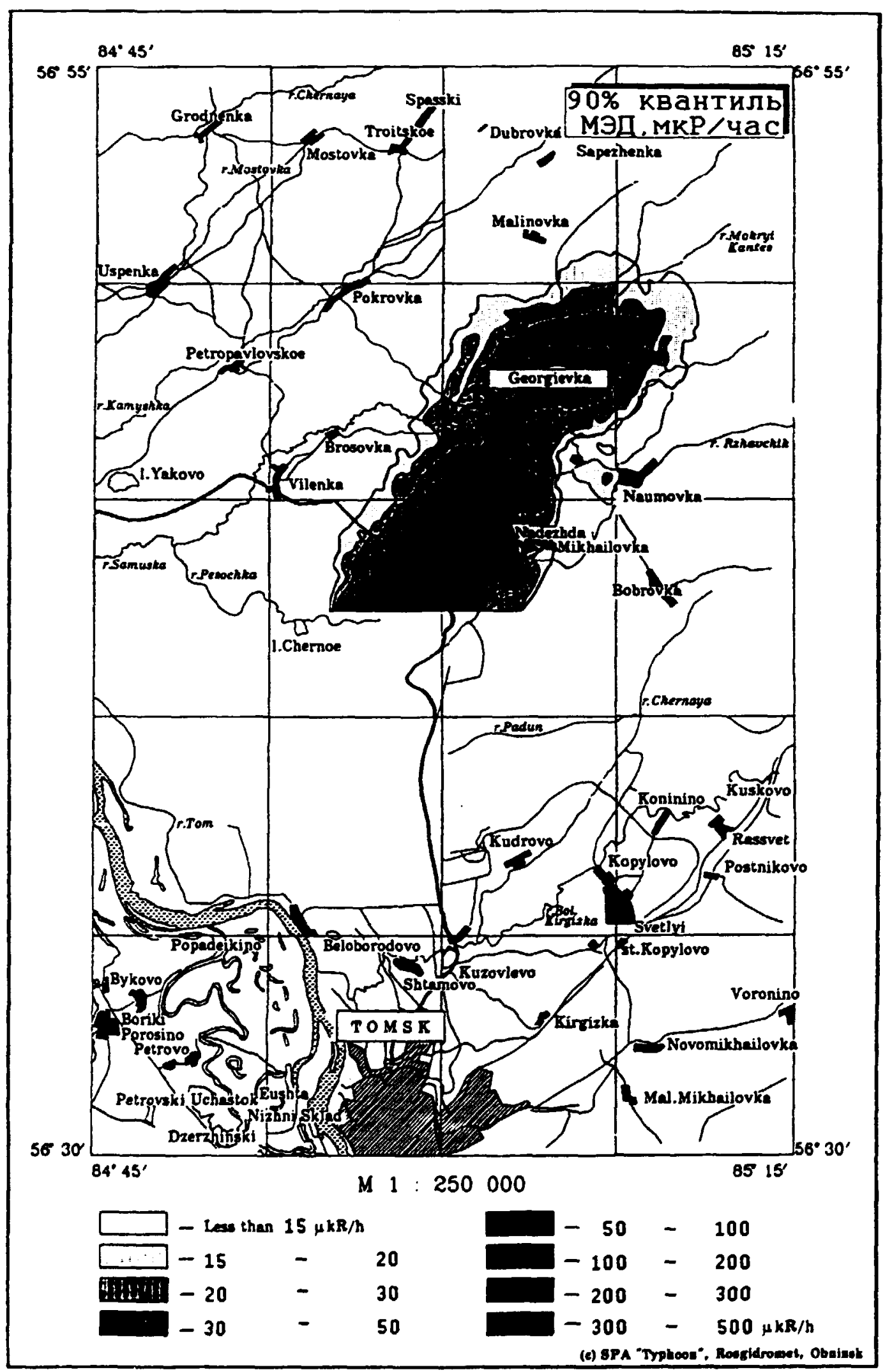

Figure 6.6. TOMSK - Synthesized map of the distribution of the gamma exposure rate $(\mu R / h)$. 
The gamma dose rates at the measuring points (buildi.ıg affected, $\mathrm{km} 28$ of the road from Tomsk to Samus, Georgievka) obtained by simulation at the calculated contamination density amounted to $10-20 \%$ of the value measured. According to prelininary estimates based on the information available at that moment (April $10,1993)$, agreement between the calculations and the measured values could have been achieved with $700 \mathrm{Ci}$ at least. The corresponding calculations were carried out. The results obtained for the $\mathrm{Nb}-95$ contamination density are presented in Fig. 6.4 (the source was simulated by two simultaneous releases from the building affected (release height $30 \mathrm{~m}, 30 \%$ of the total activity) and the ventilation stack (height $200 \mathrm{~m}, 70 \%$ of the total activity), respectively, at a deposition rate of the radioactive products of $0.2 \mathrm{~m} / \mathrm{s}$ ). They were also transmitted to Rosgidromet.

\subsection{Systematization of the measured values and data pro- cessing for an objective radiation analysis}

The following data were processed for an objective analysis of the radiation exposure in the area of the chemical combine [1]:

- Ganma dose rate measured at $\mathrm{km} 28$ of the road from Tomsk to Samus (10 measurements);

- gamma dose rates measured at ground level at different points and along 9 routes in the radioactive trace (about $\mathbf{3 0 0}$ measurements);

- gamma dose rates measured in the villages near the radioactive trace (16 villages);

- radionuclide compositions of the samples determined by the Rosgidromet analyses (11 samples);

- map of the gamna dose rate of the ground; it was prepared on the basis of the gamma aerial surveys performed by the experts of the Rosgidromet Institute for Global Climate and Ecology.

On the basis of the information available, a synthesized map of ground contamination outside the premises of the combine was set up (Fig. 6.5). Using a method developed at the data processing center of SPA "Typhoon", the data of the ground investigations as well as the map of the gamma dose rates prepared by the Rosgidromet Institute for Global Climate and Ecology were also taken into account. For the estimation of the maximum possible contaminations, a map of the gamma dose rates was set up taking into consideration the upper $90 \%$ of the confidence interval (Fig. 6.6).

As is shown by the map of ground contamination outside the premises of the combine (Fig. 6.7), the contaminated area within the radioactive trace having a gamma dose exceeding $15 \mu \mathrm{R} / \mathrm{h}$ is $89 \mathrm{~km}^{2}$ in size. The total energy released of the radioactive products in this area amounts to $3420 \mu \mathrm{R} \times \mathrm{km}^{2} / \mathrm{h}$. According to the map taking into consideration the upper $90 \%$ of the confidence interval (Fig. 6.8 , upper estimate), these values amount to $135 \mathrm{~km}^{2}$ and $7150 \mu \mathrm{R} \times \mathrm{km}^{2} / \mathrm{h}$, respectively.

By means of the values obtained by analysis of the 11 snow samples, the following mean radionuclide composition of the trace was determined: $\mathrm{Ru}-106-31 \%$, Ru-103 - 1\%, Nb-95 - 45\%, Zr-95 - 22\% (Annex 1). In precipitation samples, additional trace amounts of Pu-239 and $\mathrm{Sr}-90$ were found. For the determination of the contamination density, the following dose rates were obtained at $1 \mathrm{~m}$ height and a contamination of $1 \mathrm{Ci} / \mathrm{km}^{2}$ (with a surface film contamination being assumed): Ru-106 - 3.4 $\mu \mathrm{R} / \mathrm{h}, \mathrm{Ru}-103-8.2 \mu \mathrm{R} / \mathrm{h}, \mathrm{Nb}-95-13 \mu \mathrm{R} / \mathrm{h}$ and $\mathrm{Zr}-95-12$ $\mu \mathrm{R} / \mathrm{h}$. With the help of the ratios obtained, maps of the contamination densities 
of the major radionuclides were prepared (Figs. 6.9 throt 6 h 6.11 ). The total of the radioactive products in the area covered by the trace is $350(730) \mathrm{Ci}$. For the individual radionuclides, the following values are obtained: $\mathrm{Ru}-106-105(220) \mathrm{Ci}$, Ru-103 - 5 (10) Ci, Nb-95 - 165 (345) Ci, Zr-95 - 75 (155) Ci. The estimates taking into account $90 \%$ of the confidence interval are given in brackets. To estimate the radionuclide concentration released, a model developed by the data processing center of SPA "Typhoon" was applicd ior the reproduction of the source parameters. On the basis of the information processed, solution of the inverse problem led to the following estimates of the radionuclide content released: Ru-106 - 300 $\mathrm{Ci}, \mathrm{Ru}-103-10 \mathrm{Ci}, \mathrm{Nb}-95-470 \mathrm{Ci}$ and $\mathrm{Zr}-95-210 \mathrm{Ci}$. Hence, a total activity of $990 \mathrm{Ci}$ was released. For the estimation of the Pu-239 content released $(0.2 \mathrm{Ci})$, the $\mathrm{Zr}-\mathbf{9 5} / \mathrm{Pu}-239$ activity ratio of 1000 determined by sample analysis was used.

The ground contamination densities are represented in Figs. 6.12 through 6.15 for the most important radionuclides. They were obtained by simulation taking into account the estimated radionuclide concentrations released. For these calculations, a stochastic model was applied. It was also developed by the data processing center of SPA "Typhoon". Simulation was accomplished for two sources (building affected (height of the source up to $30 \mathrm{~m}$ ) and ventilation stack (height of the source up to $200 \mathrm{~m}$ ), respectively) assuming that $50 \%$ of the total activity was released by the lower source and that radicactive fallout from the cloud amounted to $0.2 \mathrm{~m} / \mathrm{s}$.

Variation of the Pu-239 concentration in the cloud at an altitude of $1 \mathrm{~m}$ on the road from Tomsk to Samus and in the village of Georgievka is shown in Fig. 6.16 and Fig. 6.17, respectively. The concentrations of the most important radionuclides calculated as a function of time and space by simulation allowed the individual effective dose equivalent to be estimated for the population of Georgievka when passing the radioactive cloud (Fig. 6.18). The integral dose for 1 hour is about 1 mrem. Here, the share of Pu-239 in the dose due to inhalation is $0.5 \mathrm{mrem}$. The dose values were calculated in accordance with the method described in [15]. 


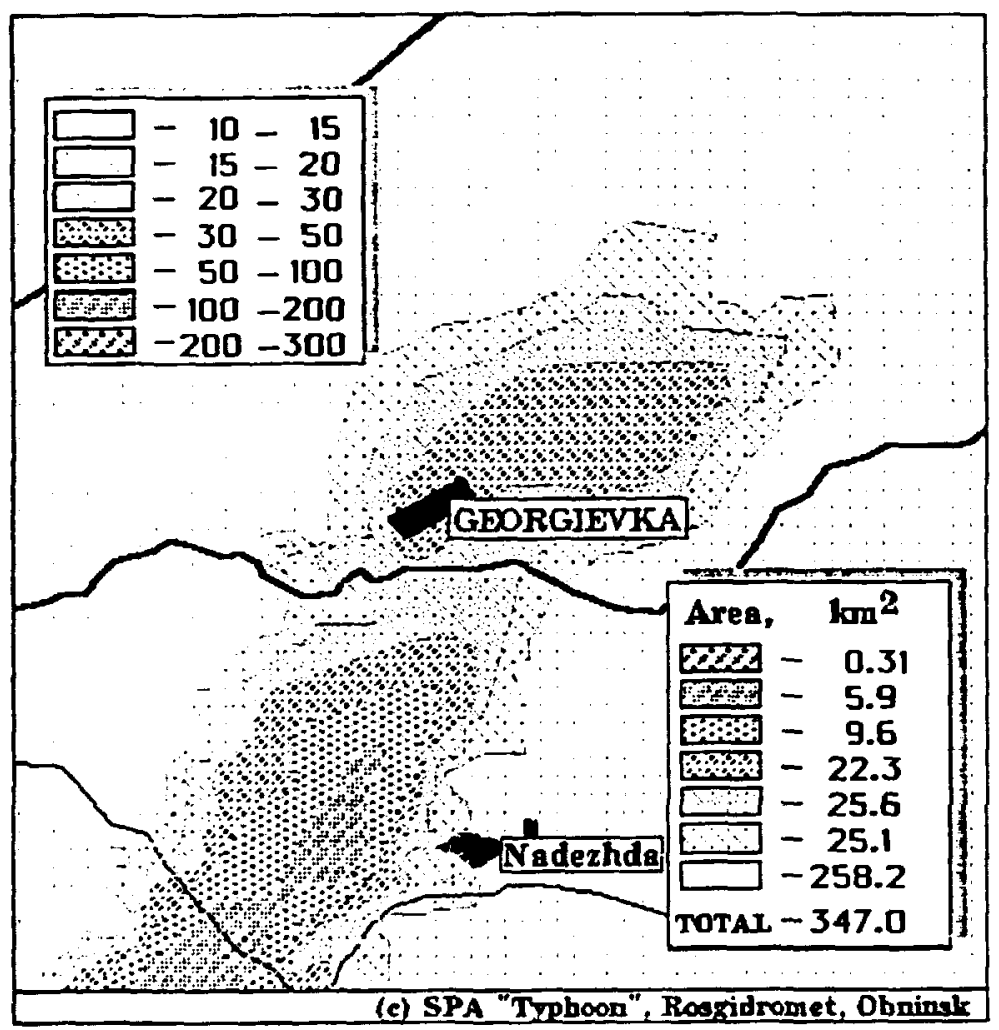

Figure 6.7.

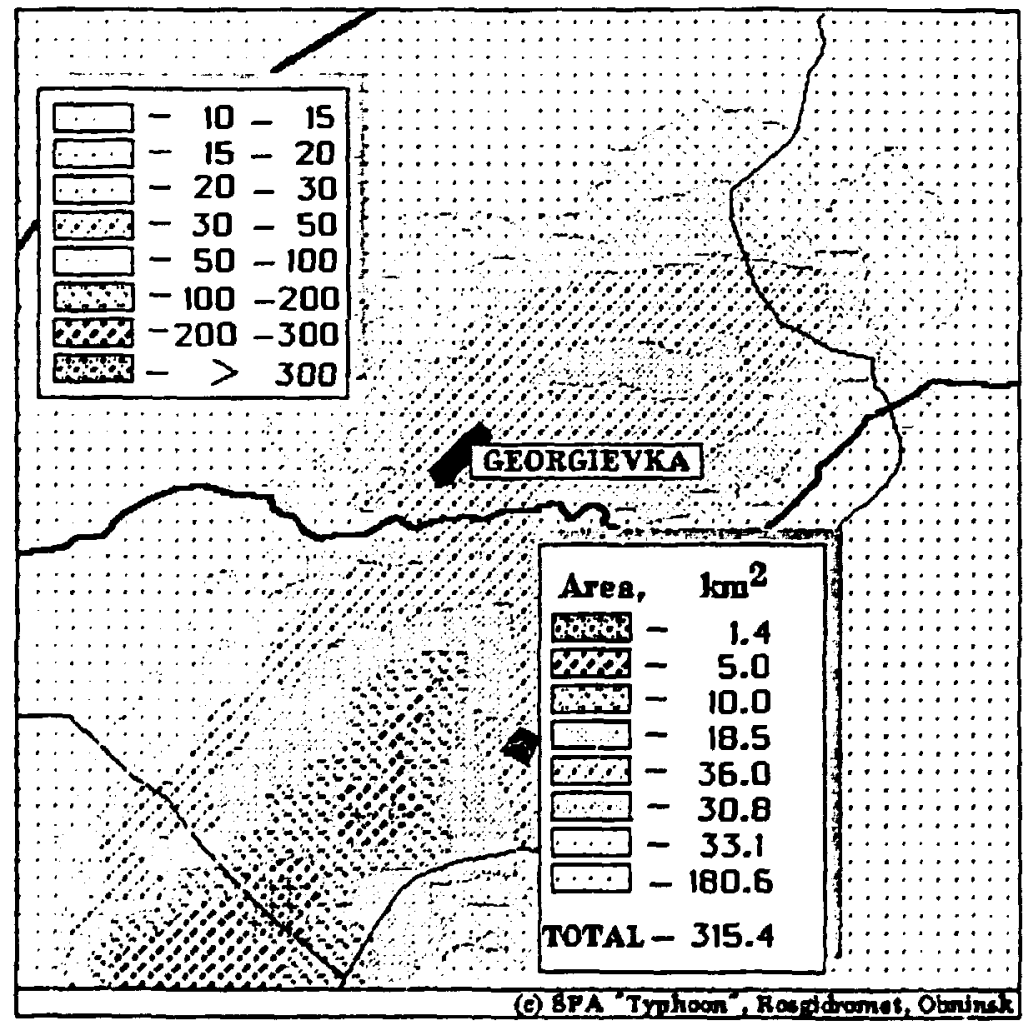

Figure 6.8.

Risø-R-750(EN) 


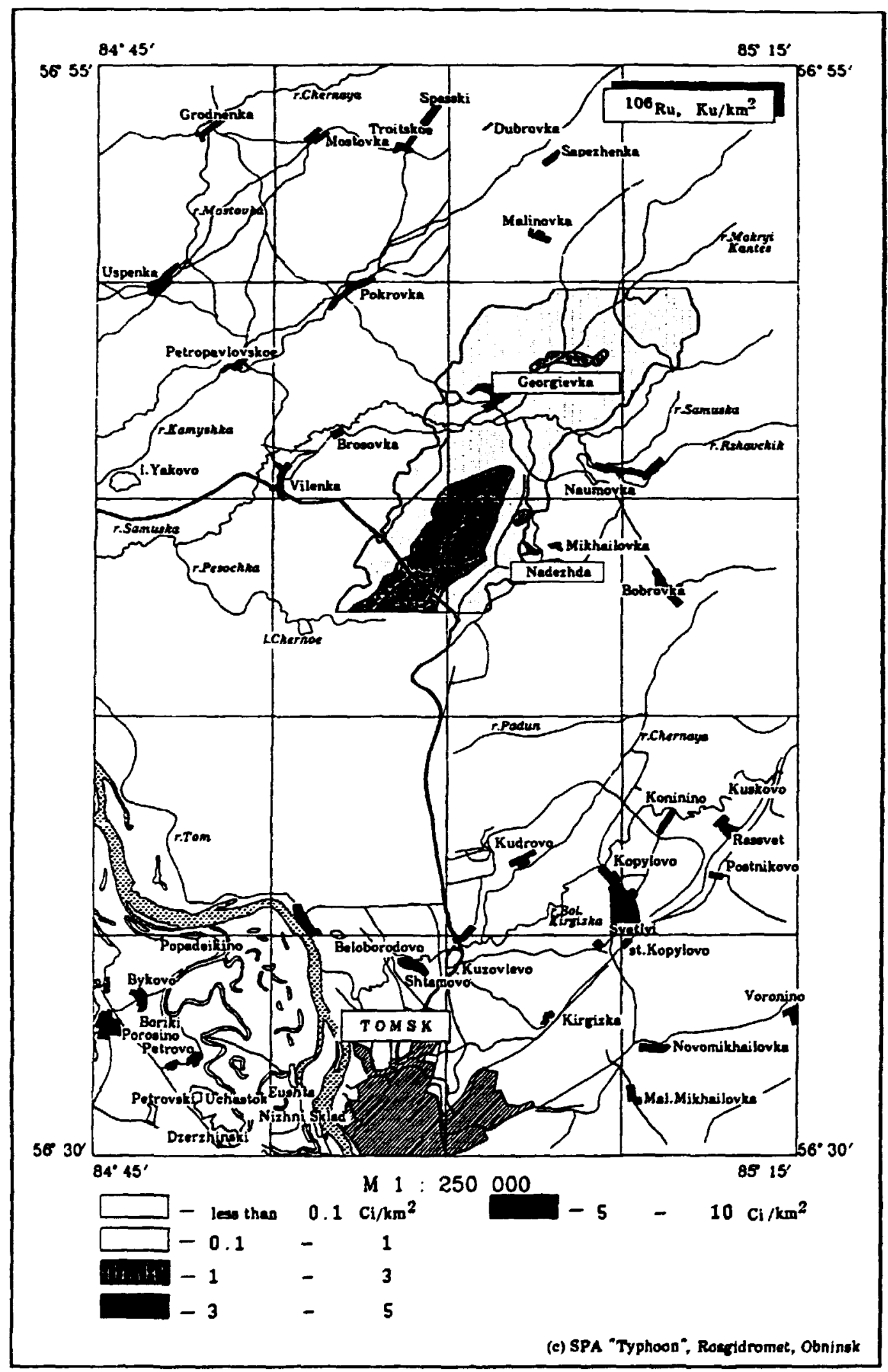

Figure 6.9. TOMSK - Map of the gamma dose rates as determined by the aerial surveys. 


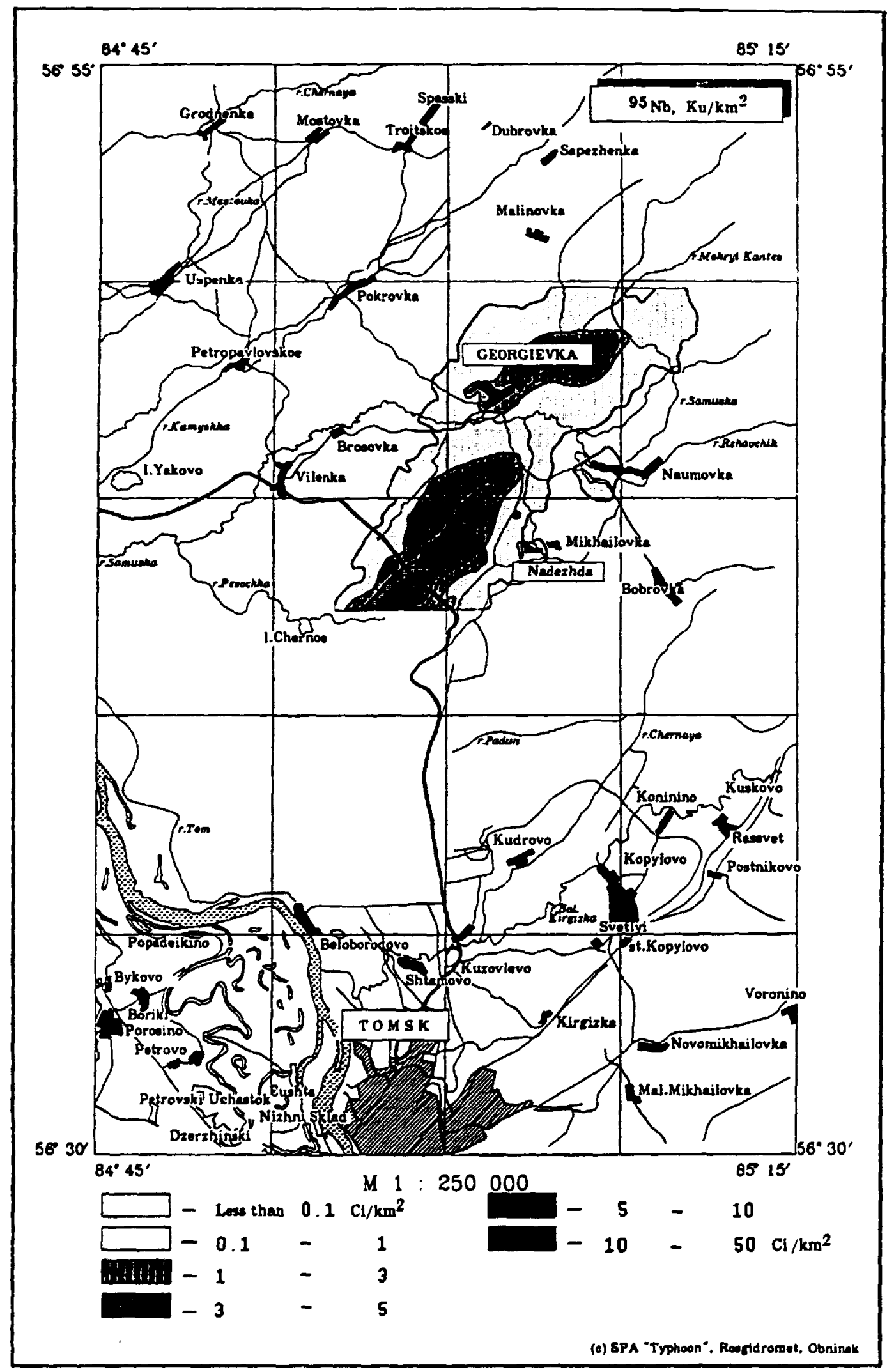

Figure 6.10. TOMSK - Map of the Ru-106 contamination density according to the values measured $\left(\mathrm{Ci} / \mathrm{km}^{2}\right)$. 


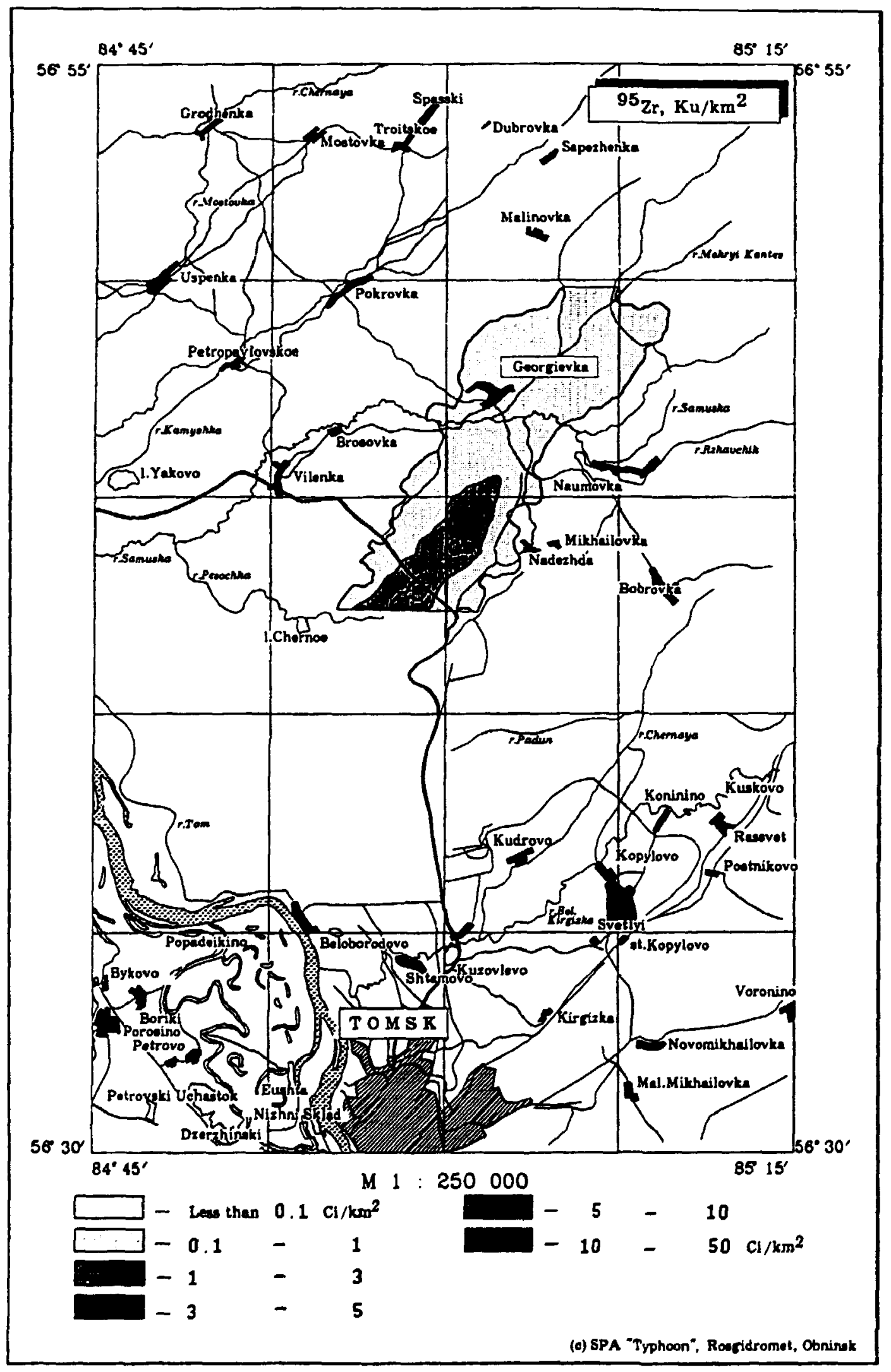

Figure 6.11. TOMSK - Map of the Nb-95 contamination density according to the values measured $\left(C i / \mathrm{km}^{2}\right)$. 


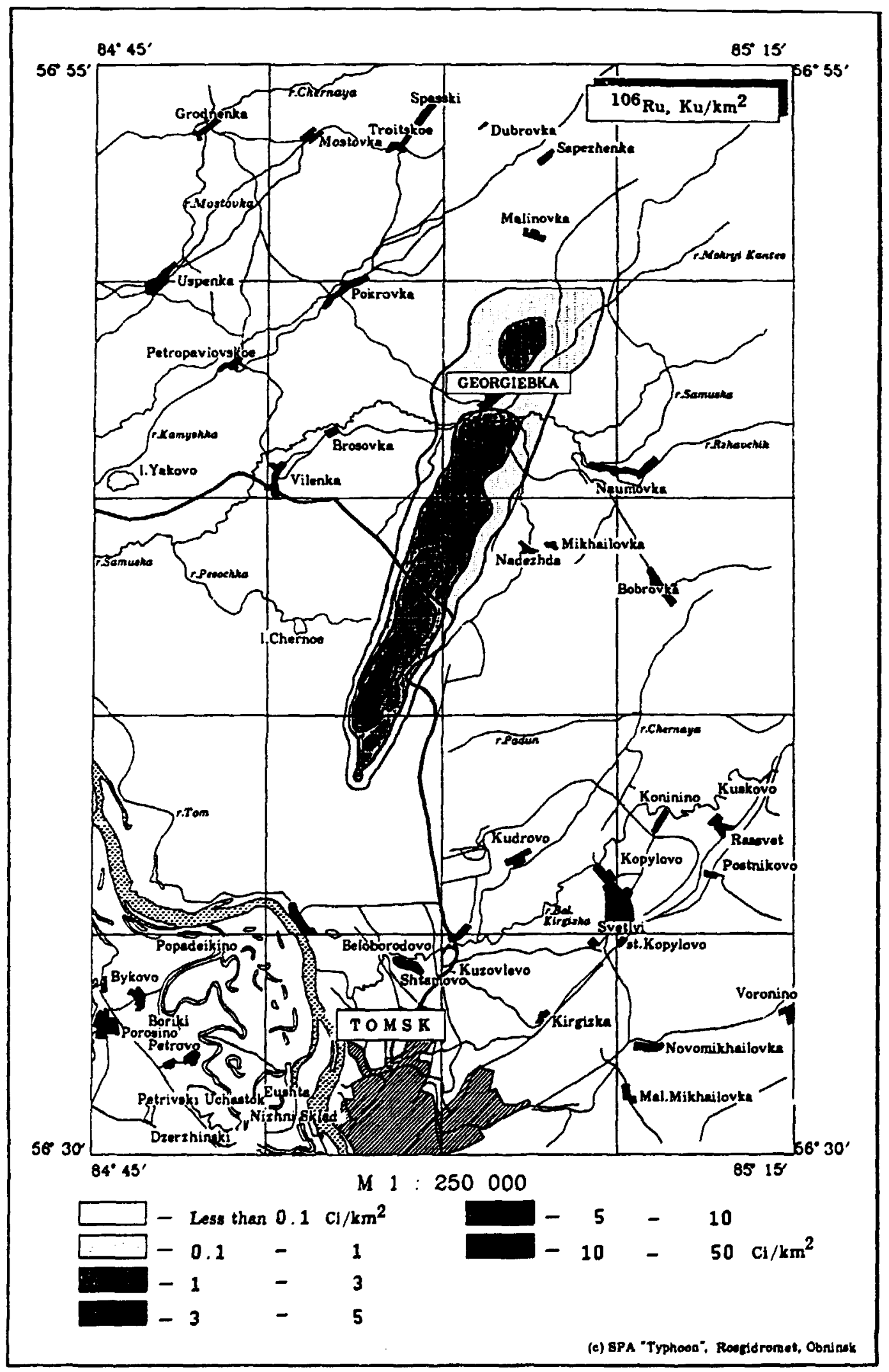

Figure 6.12. TOMSK - Map of the Zr.95 contamination density according to the values measured $\left(\mathrm{Ci} / \mathrm{km}^{2}\right)$. 


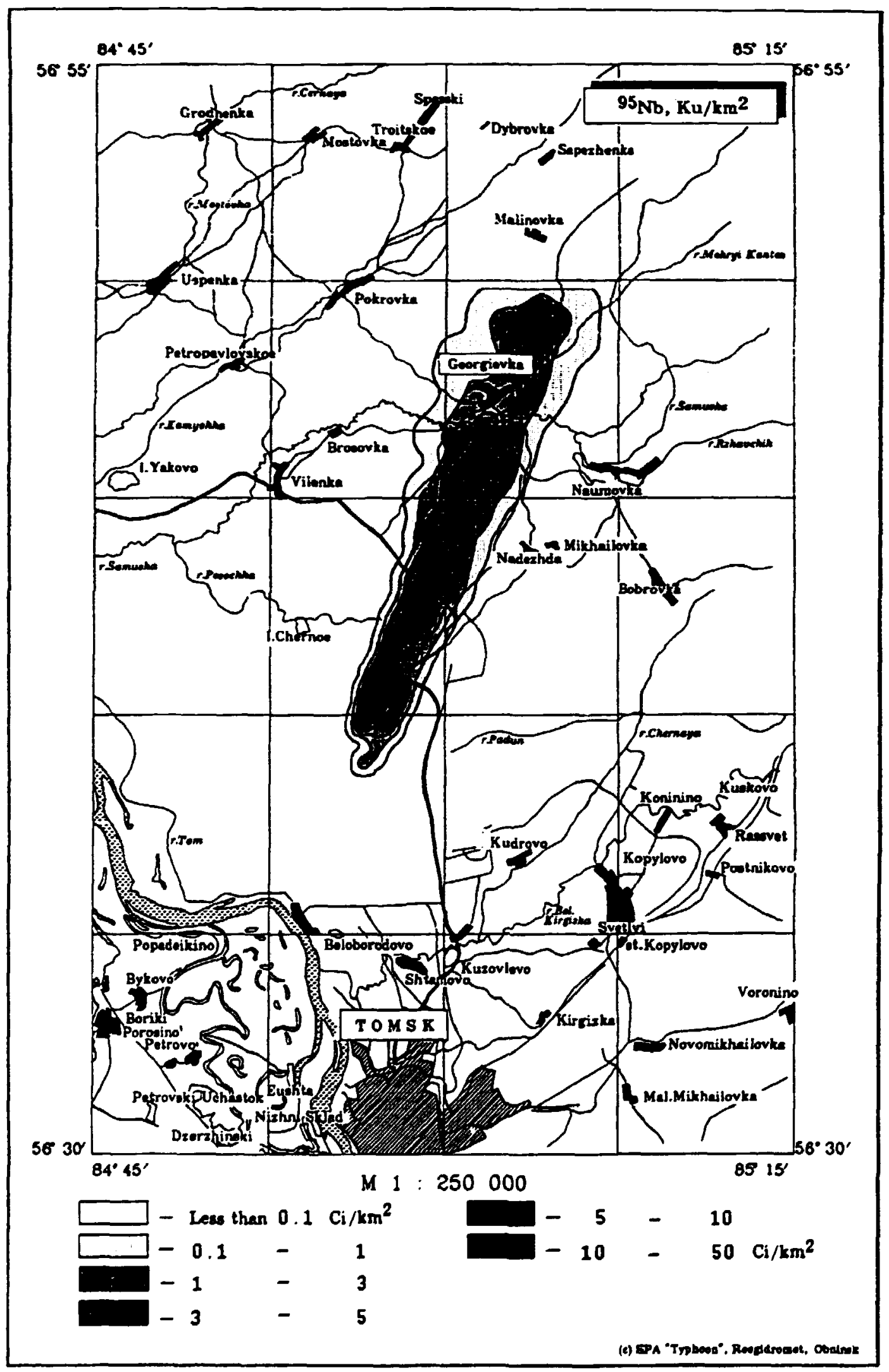

Figure 6.13. TOMSK - Map of the Ru-106 contamination density according to the simulation resulls of SPA "TYPHOON" (Ci/ $\left./ \mathrm{km}^{2}\right)$. 


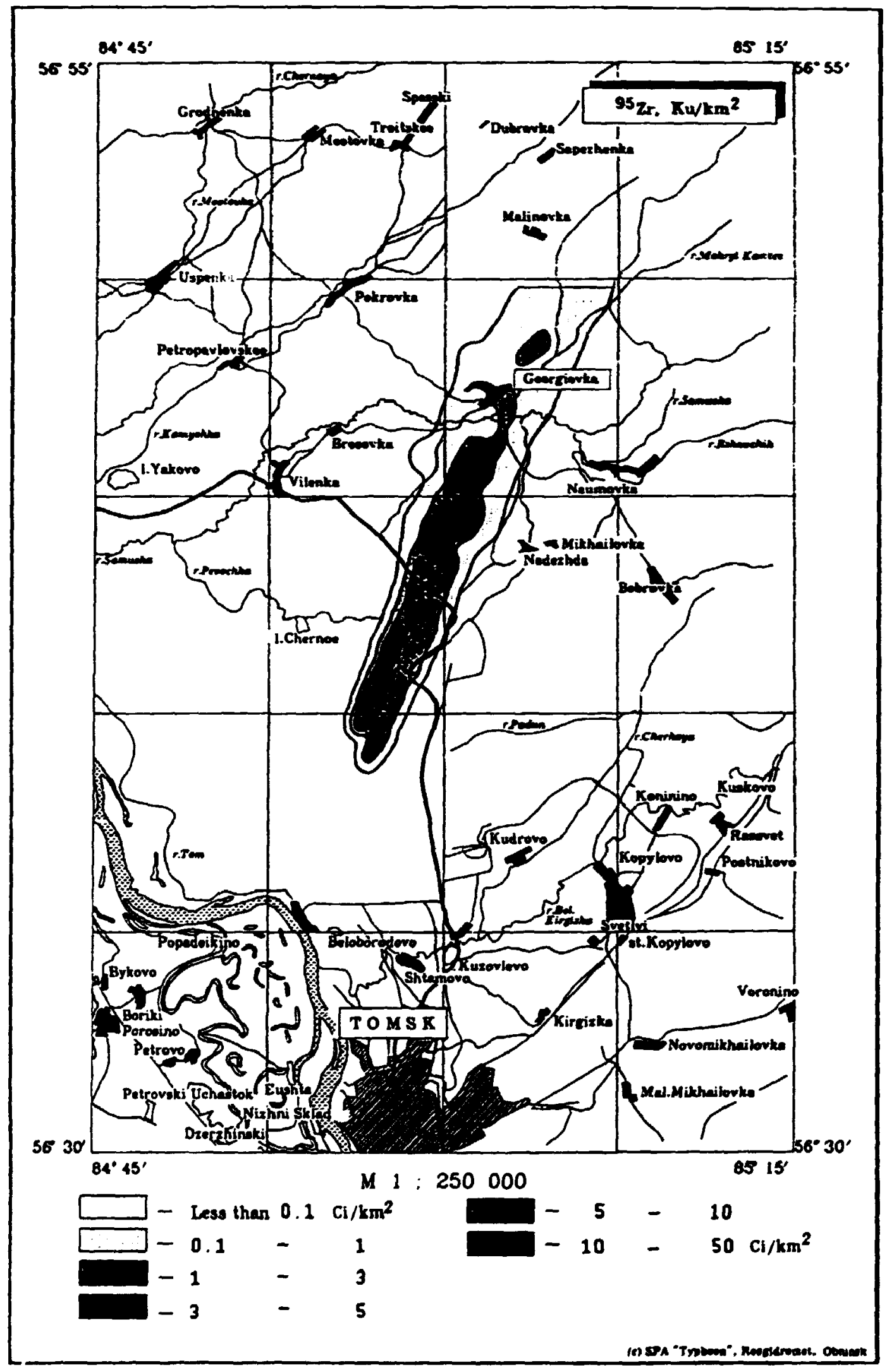

Figure 6.14. TOMSK - Map of the Nb-95 contamination density according to the simulation resulls of SPA "TYPHOON" $\left(\mathrm{Ci} / \mathrm{km}^{2}\right)$. 


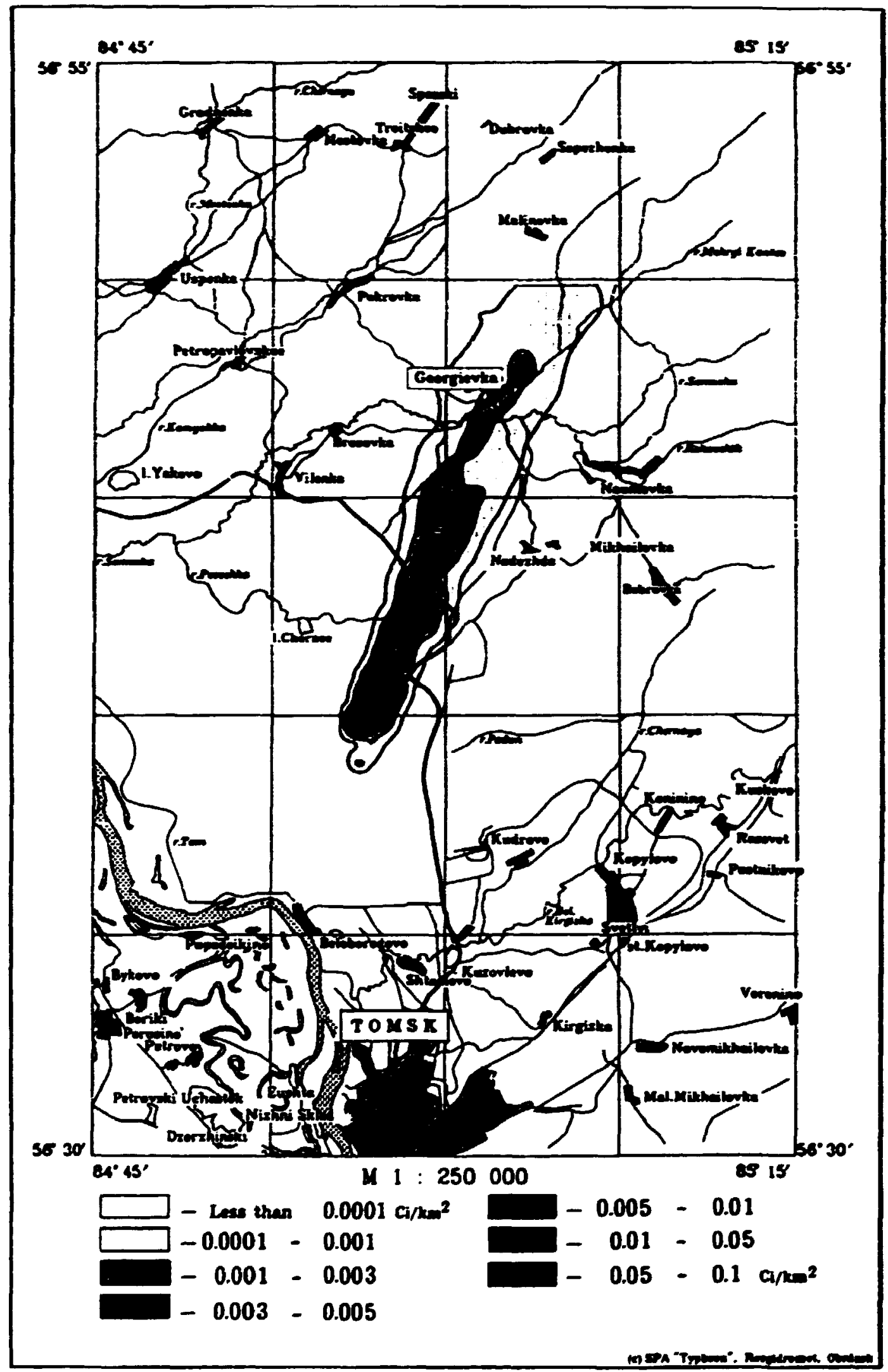

Figure 6.15. TOMSK - Map of the Zr-95 contemination density ecconding to the simulation results of SPA "TYPHOON" $\left(\mathrm{Ci} / \mathrm{km}^{2}\right)$. 


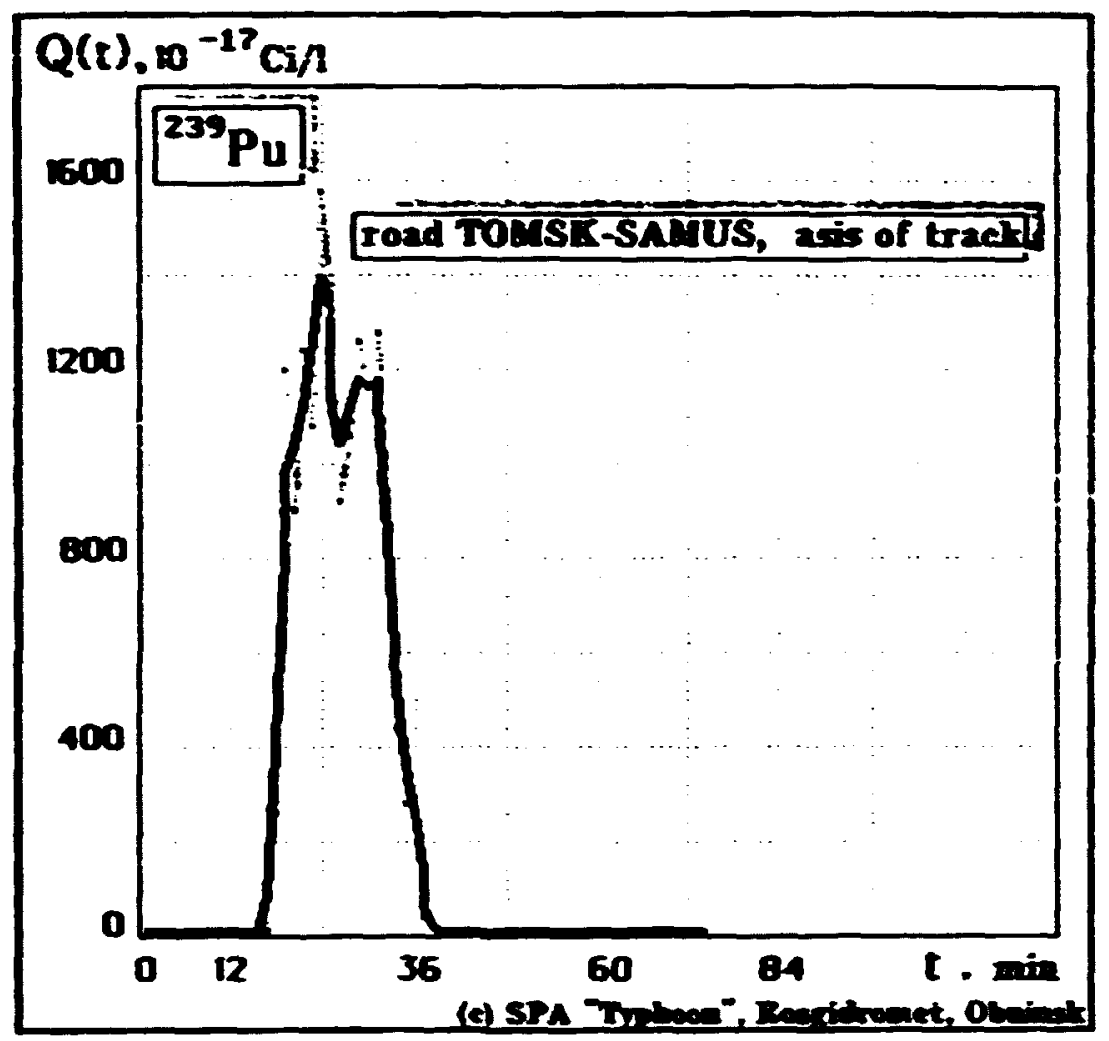

Figure 6.16. TOUSK - Jep of the Pa-zJs conlemention densilg eccording to the simelation resalls of SPA 'TYPHOON $\left(\mathrm{Ci}^{2} \mathrm{~km}^{2}\right)$.

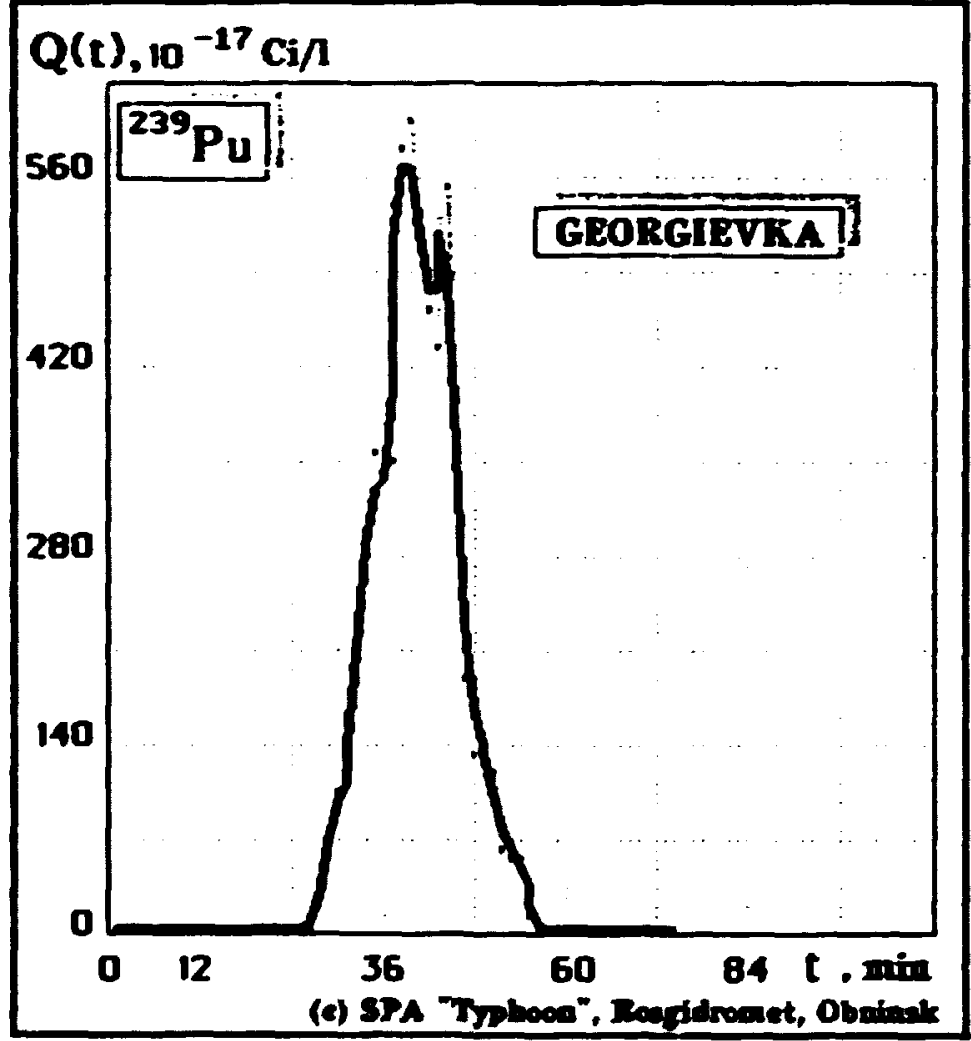

Figure 6.17.

Rivo-R-750(FN) 


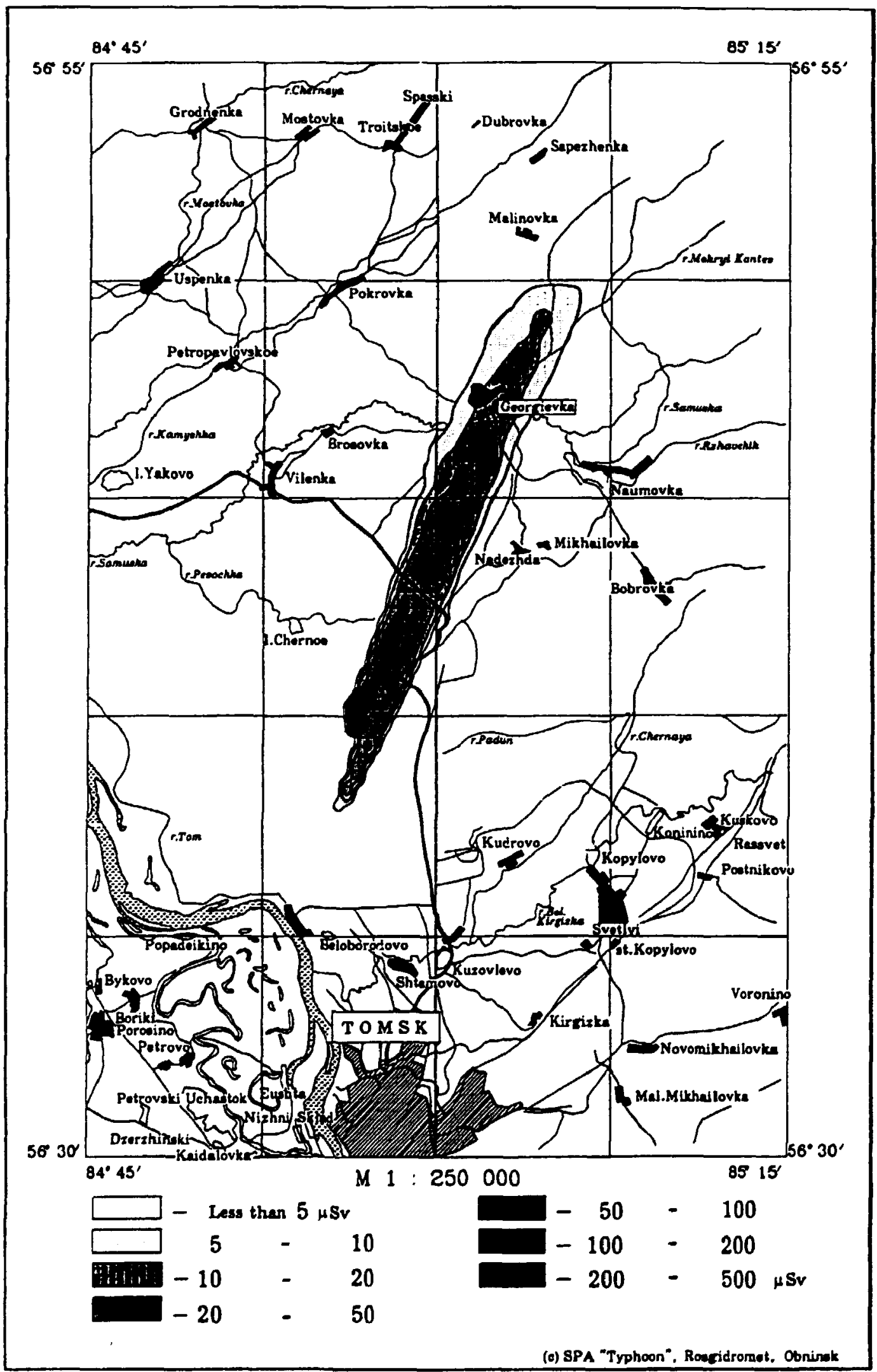

Figure 6.18. TOMSK - Individual effective dose equivalent according to the simulation results of SPA "Typhoon" (Sv). 


\section{Concluding Remarks}

1. On the basis of the work (ground investigations and gamma aerial surveys) carried out jointly by the Rosgidromet organizations and Berezovgeologiya, data on the radiation exposure in Russia were obtained shortly after the accident of April 6, 1993 already. These data were transmitted to interested institutions as well as to local and central public information authorities.

2. The measurements performed on April 11 and 12,1993 indicated that within the isolines of $10 \mu \mathrm{R} / \mathrm{h}$ a contaminated area of up to $25 \mathrm{~km}$ in length and up to $6 \mathrm{~km}$ in width extended towards the northeastern direction. Thus, the contaminated area outside of the premises of the combine covered about $100 \mathrm{~km}^{2}$.

3. The total amount of radioactive substances in this area was $530-590 \mathrm{Ci}$. Isotope composition of the radioactive trace was determined by ruthenium$103(1 \%)$, ruthenium-106 (31\%), zirconium-95 (22\%), niobium-95 (45\%) and plutonium-239 (0.02\%).

4. A typical feature of the contamination is its considerable heterogeneity. It is caused by the existence of "hot" particles with an activity of up to 10 $11 \mathrm{Ci} /$ particle.

5. The small village of Georgievia is situated in the contaminated area. Here, gamma exposure rate varied between 14 and $42 \mu \mathrm{R} / \mathrm{h}$ at $1 \mathrm{~m}$ height. Conservative estimation of the maximum external radiation dose of the population of Georgievka yielded a value of $100 \mathrm{mrem} /$ year.

6. The $P_{u}-239$ inlialation dose of the population of Georgievka when passing the radioactive cloud did not exceed $1.5 \mathrm{mrem}$.

7. A prognosis was made with regard to water contamination of the rivers Samuska and Tom during the flood in spring. Furthermore, contamination of the air layer adjacent to the ground resulting from the wind transport of radionuclides due to agricultural work or the passing of vehicles in the summer months at Georgievka was predicted. The values were far below the limits fixed in accordance with the valid radiation protection regulations.

At the same time, it must be pointed out, horrever, that radionuclide concentration of the snow water may exceed the limits specified for drinking water. Water contamination shuuld therefore be measured in wells or small closed natural waters.

8. According to the data measured by the meteorological stations, the radioactive products were not entrained beyond the borders of the country. 


\section{Annex 1}

Calculation of the Factors of Conversion of the Dose Rate Distribution of the Ground into the Contamination Density of Individual Radionuclides

On the basis of the gamma aerial survey of the contaminated area, a map was set up illustrating the distribution of the gamma exposure rate of the ground. For the preparation of maps of ground contamination by individual radionuclides, the factors of conversion of the total dose rate $N_{\gamma}$ into the surface contamination density of each $i$-th radiosiotope $A_{i}$ must be known:

$$
A_{i}=B_{i} N_{\gamma}
$$

Dose rate of the ground is determined by adding the gamma radiations of the individual isotopes

$$
N_{\gamma}=\sum_{i}^{n} K_{i} A_{i} \quad(n=1,2, \ldots, n),
$$

where $K_{i}$ is the dose coefficient in $(\mu \mathrm{R} / \mathrm{h}) /\left(\mathrm{Ci} / \mathrm{km}^{2}\right)$. With the activity share of each $i$-th isotope in the total contamination density $A$ being $p_{i}=A_{i} / A$, equation (2) may also be expressed as follows:

$$
N_{,}=A \sum_{i}^{n} K_{i} p_{i}=A K .
$$

Here, $K=\sum_{i} K_{i} p_{i}$ is related to the actual mixture of $\mathrm{n}$ isotopes investigated. From this, the total ground contamination density by all isotopes may be derived:

$$
A=\left(\sum_{i}^{n} K_{i} p_{i}\right)^{-1} N_{\gamma}=B N_{\gamma} .
$$

As $A_{i}=p_{i} A$, the following formula for the calculation of the ground contamination density by the $i-t, h$ isotope is obtained from (4):

$$
A_{i}=\frac{p_{i}}{\sum_{i}^{n} K_{i} p_{i}} N_{\gamma} \text {. }
$$

Hence, the factors of conversion of the gamma dose rate into the surface contamination density can be represented as follows:

$$
V=\left(\sum_{i}^{n} K_{i} p_{i}\right)^{-1} ; \quad B_{i}=p_{i}\left(\sum_{i}^{n} K_{i} p_{i}\right)^{-1}
$$

Obviously, the conversion factors $B$ and $B_{i}$ are dependent on the isotope composition of the gamma emitters and their dose factors only.

Let us now determine the formula for the conversion of the gamma exposure rate of the ground measured $N_{0 \gamma}$ into the density of isotope contamination of the surface $A_{i}$ for the radioactive trace generated following the accident at the chemical combine on April 6, 1993.

Sampling of the snow and simultaneous measurements of the dose rate in the contaminated area were performed by ZapSibgidromet experts along the routes M1 - M4 both away from and near the road from Tomsk to Samus (up to $50 \mathrm{~m}$ ) as well as in the most contaminated section at $\mathrm{km} \mathrm{28}$. As the snow near the road had already begun to thaw, samples were also taken from the upper soil layer.

All samples were observed to have stable isotopic ratios. The activities of the individual isotopes in percent are given below. 


$\begin{array}{lcccc}\begin{array}{l}\text { Isotope } \\ \quad\end{array} & { }^{103} \mathrm{Ru} & { }^{106} \mathrm{Ru} & { }^{95} \mathrm{Zr} & { }^{95} \mathrm{Nb} \\ & 1 & 2 & 3 & 4 \\ \text { Mean value for routes M1-M4 } & 1.5 & 32.4 & 22.8 & 43.3 \\ \text { Mean value for km } 28 & 1.3 & 29.8 & 20.8 & 48.1 \\ \text { Mean value } & & & & \\ \text { Mean } & 1.4 & 31.1 & 21.8 & 45.7\end{array}$

For the calculation of the dose coefficients $K_{i}$ on the basis of the experimental data, equation system (2) with four unknown quantities $K_{1}, K_{2}, K_{3}$ and $K_{4}$ must be solved. Unfortunately, the measurements of $A_{i}$ near the road turned out to be too small, which obviously had to be attributed to partial penetration of the isotopes into the soil. Correct sampling of the ground was very difficult due to the partly molten snow. Snow samples taken in the taiga far away from the road indicated that practically the entire activity was concentrated on the upper 1 $2 \mathrm{~cm}$ of the snow layer [23]. Due to the very small number of measured values available and the strong fluctuations of the results for $A_{i}$, which were caused by the existence of "hot" particles in the samples, ${ }^{95} \mathrm{Zr}$ and ${ }^{95} \mathrm{Nb}$ could only be approximated, $K_{3} \approx K_{4}=1 \pi(\mu \mathrm{R} / \mathrm{h}) /\left(\mathrm{Ci} / \mathrm{km}^{2}\right)$. This nearly corresponds to the theoretical value of $K=14$ which was determined when calculating the radiation exposure after the Chernobyl accident [24]. For ${ }^{103} \mathrm{Ru}$ and ${ }^{106} \mathrm{Ru}$, estimations of this type could not be performed on the basis of the data measured in the Tomsk trace, as the values of $A_{1}$ and $K_{2}$ were too small. For this reason, the theoretical values of $\mathrm{Ki}$ for film contamination of an infinite, homogeneously contaminated plane indicated in [15] were applied in the following calculations:

$\begin{array}{ccccc}\text { lsotope } & { }^{103} \mathrm{Ru} & { }^{106} \mathrm{Ru} & { }^{95} \mathrm{Zr} & { }^{95} \mathrm{Nb} \\ K_{i}(\mu \mathrm{R} / \mathrm{h}) /\left(\mathrm{Ci} / \mathrm{km}^{2}\right) & 8.2 & 3.4 & 12 & 13\end{array}$

Using these values of $K_{i}$ and the above values of $p_{i}$, a total of the radioactive products of the Tomsk accident of $K=9.7(\mu \mathrm{R} / \mathrm{h}) /\left(\mathrm{Ci} / \mathrm{km}^{2}\right)$ is obtained. This corresponds to a value of $B=0.115\left(\mathrm{Ci} / \mathrm{km}^{2}\right) /(\mu \mathrm{R} / \mathrm{h})$.

According to (1) and (6), ground contamination density of the individual isotopes can be calculated as follows:

$$
\begin{array}{ll}
\text { For }{ }^{{ }^{103}} \mathrm{Ru}_{\mathrm{u}} & A_{1}=1.4 \cdot 10^{-3}\left(N_{\gamma 0}-N_{\gamma \phi}\right) . \\
\text { For }{ }^{{ }^{106} \mathrm{Ru}} \quad A_{2}=3.2 \cdot 10^{-2}\left(N_{\gamma 0}-N_{\gamma \phi}\right) . \\
\text { For }{ }^{95} \mathrm{Zr} & A_{3}=2.2 \cdot 10^{-2}\left(N_{\gamma 0}-N_{\gamma \phi}\right) . \\
\text { For }{ }^{95} \mathrm{Nb} & A_{1}=4.7 \cdot 10^{-2}\left(N_{\gamma 0}-N_{\gamma \phi}\right) .
\end{array}
$$

For the total of these isotopes

$$
A=0.115\left(N_{\gamma 0}-N_{\gamma \phi}\right),
$$

where $N_{\gamma 0}$ is the dose rate measured and $N_{\gamma \phi}$ the gamma background in $\mu \mathrm{R} / \mathrm{h}$. The density of radioactive contamination of the ground is denoted by $A_{i}$ or $A$ in $\mathrm{Ci} / \mathrm{km}^{2}$.

In accordance with the isotopic ratio ${ }^{239,240} \mathrm{Pu} /{ }^{95} \mathrm{Zr}=3.4 \times 10^{-4}$, the formula for the estimation of the contamination density of the ground by these isotopes has the form of

Riso-R-750(EN) 


$$
A_{\text {pu }}=7.6 \cdot 10^{-6}\left(N_{\gamma 0}-N_{\gamma \phi}\right) \quad \mathrm{Ci} / \mathrm{km}^{2} \text {. }
$$

In March 1993 already, an aerial survey of the gamma background had been carried out by ZapSibgidromet along several routes. On the basis of the values obtained, a gamma background of $N_{\gamma} \approx 10 \mu \mathrm{R} / \mathrm{h}$ can be selected for the formulas (7) through (12).

\section{References}

1. Vladimirov V.A., Nedelchuk I.P., Subbotin G.I., Gorev S.S., Vasnev V.D., Bashevoi S.I. (1993). Report about the state of radiation in the area affected by the accident at the Siberian chemical combine (Tomsk-7), April 13, 1993 (in Russian). In coordination with the Ministry of Atomic Energy, the Ministry of Health, the Ministry of Environmental Protection, Rosgidromet, and the Committee for States of Emergency of the Tomsk region. Confirmed by the chairman of the Russian State Committee for States of Emergency, S. Shoigu, April 15, 1993

2. Ivanov A.B., Nosov A.V., Reut B.Ya., Verbitski B.B., Popov Yu.S. (1993). Information on the results of the express analysis of radiation exposure in the surroundings of the Siberian chemical combine "Tomsk-7" (in Russian). April 15, 1993.

3. Tsybikov N.A., Zinenko V.I., Vozzhennikov O.I., Artemov E.M., Chirkov V.A. (1993). Preliminary estimation and prognosis of radiation exposure resulting from the accident at the Siberian chemical combine (Tomsk 7) (in Russian). Report. Novosibirsk, 1993.

4. Pavlotskaya F.I., Goryachenkova T.A., Fedorova Z.M. et al. (1984). Method of plutonium determination in the soil (in Russian). Radiokhimiya, 26, No. 4, $460-466$.

5. Instructions and methods for the estimation of radiation exposure in a contaminated area (in Russian). Confirmed by the president of the Interauthority Commission for Environmental Radiation Control, Yu.A. Izrael.

6. Manual of Protective Action Guides and Protective Actions for Nuclear Incidents. - US EPA, Washington, 1991.

7. Garger E.K. et al. (1990). Estimation of the parameters of the wind transport of radionuclides in the surroundings of the Chernobyl nuclear power plant (in Russian). Meteorologiya i gidrologiya, 1, 5-10.

8. Transuranium elements in the environment (in Russian). Translation from English, ed. U.S. Henson. Moscow, Energoatomizdat, 1985, 344 pp.

9. Koloskov 1.A., Pisarev V.V., Sinitsina Z.L. (1986). Washout of Sr-90 from various soils and grounds (in Russian). Pochvovedenie, 2, 34-45.

10. Cliernobyl: Radioactive contamination of the environment (in Russian). Ed. Yu.S. Izrael, Leningrad, Gidrometeoizdat, 1990, 250 pp.

11. Borzilov V.A., Vozzhennikov O.I. et al. (1989). Physico-mathematical simulation of the washout processes of long-lived radionuclides from waters in the 30-km zone surrounding the Chernobyl nuclear power plant (in Russian). Meteorologiya i gidrologiya, 1, 5-13.

12. Vozzhennikov O.1. et al. (1990). Chamber model for the prognosis of water contamination (in Russian). Vodnye resursy, 6, 94-97. 
13. Vozzhennikov O.I., Dragolyubova I.V. (1992). Self-purification rate of the soil layer after a nuclear power plant accident (in Russian). In: "Ecological aspects of nuclear accidents" (in Russian), Moscow, Energoatomizdat, 1992, 131-141.

14. Mikkelsen, T, Larsen, S.E. (1984). Description of RISO PUFF Diffusion Model, Nuclear Technology, 67, 56-65.

15. Methods for the calculation of the spread of radioactive substances from a nuclear power plant and the irradiation of the population in the surroundings (in Russian). Technical standard 38.220.56-84. Interatomenergo, Moscow, Energoatomizdat, 1984. 
Title and author(s)

Analysis and prognosis of radiation exposure following the accident at the Siberian chemical combine Tomsk-7

S.M. Vakulovski, V.M. Shershakow, R.V. Borodin, O.I. Vozzhennikov, Ya.l. Gaziev, V.S. Kosykh, K.P. Makhon'ko, and V.B. Chumicher

\begin{tabular}{|c|c|c|}
\hline ISBN & & TSSIN \\
\hline $87-550-1980-3$ & & $0106-2840$ \\
\hline Dept. or group & & Date \\
\hline Meteorology and Wind Energy & & October 1994 \\
\hline Groups own reg. number(s) & Project/contract No. & \\
\hline Tables & Illustrations & References \\
\hline 47 & 20 & 15 \\
\hline
\end{tabular}

Abstract (Max. 2000 char.)

On the basis of the work (ground investigations and gamma serial surveys) carried out jointly by the Rosgidromet organizations and Berezorgeologiya, data on the radiation exposure in Russia were obtained shortly after the accident of April 6, 1993 already. These dats were transmitted to interested institutions.

The mensurements performed on April 11 and 12,1993 indicated that within the isolines of $10 \mu \mathrm{R} / \mathrm{h}$ a contaminaced area of up to $25 \mathrm{~km}$ in length and up to $6 \mathrm{~km}$ in width extended towards the northeastern direction. Thus, the contaminated area outside of the premises of the combine covered about $100 \mathrm{~km}^{2}$. The total amounl of radioactive substances in this area was 530 - $590 \mathrm{Ci}$. lsotope composition of the radiaactive trace was determined by ruthenium-103 (1\%), ruthenium-106 (31\%), zirconium-95 (22\%), niobium-95 (45\%) and plutonium-239 (0.02\%).

Contamination heterogeneity is caused by the existence of "hot" particles with an activity of up to 10-11 Ci/particle.

In the contaminated area the gamma exposure race varied between 14 and $42 \mu \mathrm{R} / \mathrm{h}$ at $1 \mathrm{~m}$ height, yielding the maximum external radiation dose $100 \mathrm{mrem} / \mathrm{year}$ for the population of Georgerka. The Pu-239 inhalation dose of the population of Georgievka when passing the radioactive cloud did not exceed 1.5 mrem.

A prognosis was made with regard to water contamination of the rivers Samuska and Tom during the flood in spring. Furthermore, contamination of the air layer adjacent to the ground resulting from the wind transport of radionuclides in the summer months at Georgievka was predicted. The values were far below the limits fixed according to the valid radiation protection regulations. However, that radionuclide concentration of the snow water may exceed the limits specified for drinking water.

According to the data measured by the meteorological stations, the radioactive products were not entrained beyond the borders of the coundry. Source estimation was successfully obtained using RIMPUFF, the Ris on-line puff diffusion model, in backfitting mode.

Descriptors INISTEDB

ACCIDENTS; ALPHA-BEARING WASTES; ATMOSPHERIC CIRCULATION; ATMOSPHERIC PRECIPITATIONS; EXPLOSIONS; FISSION PRODUCT RELEASE; FUEL, REPROCESSING PLANTS; HYDROLOGY; MATHEMATICAL MODELS; METEOROLOGY; MONITORING; ORGANIC SOLVENTS; R CODES; RADIATION DOSES; RUSSIAN FEDERATION; SURFACE CONTAMINATION

Available on request from:

Risø Library, Risø National Laboratory (Risø Bibliotek, Forskningscenter Risø)

P.O. Box 49, DK-4000 Roskilde, Denmark

Phone (+45) 46774677 , ext. 4004/4005 - Telex 43116 . Fax (+45) 46755677 


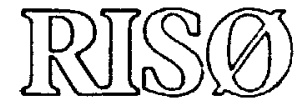

Riso-R-750(EN)

ISBN 87-550-1980-3

ISSN 0106-2840

Available on request from:

Riso Library

Riso National Laboratory

P.O. Box 49, DK-4000 Roskilde, Denmark Phone +4546774677 , ext. 4004/4005

Tclex 43116, Fax +45 46755627

\section{Objective}

The objective of Riso's research is to provide industry and society with new potential in three main areas:

- Energy technology and energy planning

- Enviranmental aspects of energy, industrial and plant production

- Muterials and measuring techniques for industry

As a special obligation Riso maintains and extends the knowledge required to advise the authorities on nuclear matters.

\section{Research Profile}

Risø's research is long-term and knowledge-oriented and directed toward areas where there are recognised needs for new solutions in Danish society. The programme areas are:

- Combustion and gasification

- Wind energy

- Energy technologies for the furure

- Energy planning

- Environmental aspects of energy and industrial production

- Environmental aspects of plant production

- Nuclear safery and radiation protection

- Materials with new physical and chemical properties

- Structural materials

- Optical measurement techniques and information processing

\section{Transfer of Knowledge}

The results of Risø's research are transferred to industry and authorities through:

- Research co-operation

- Co-operation in RED consortia

- RED clubs and exchange of researchers

- Centre for Advanced Technology

- Patenting and licencing activities

To the scientific world through:

- Publication activities

- Co-operation in national and international nerworks

- PhD- and Post Doc. education

\section{Key Figures}

Risø has a staff of just over 900 , of which more than 300 are scientists and 80 are PhD and Post Doc. students. Risø's 1995 budget totals DKK $476 \mathrm{~m}$, of which $45 \%$ come from research programmes and commercial contracts, while the remainder is covered by government appropriations. 